$\left\{\begin{array}{l}\text { JOURNAL OF ETHNOBIOLOGY } \\ \text { AND ETHNOMEDICINE }\end{array}\right.$

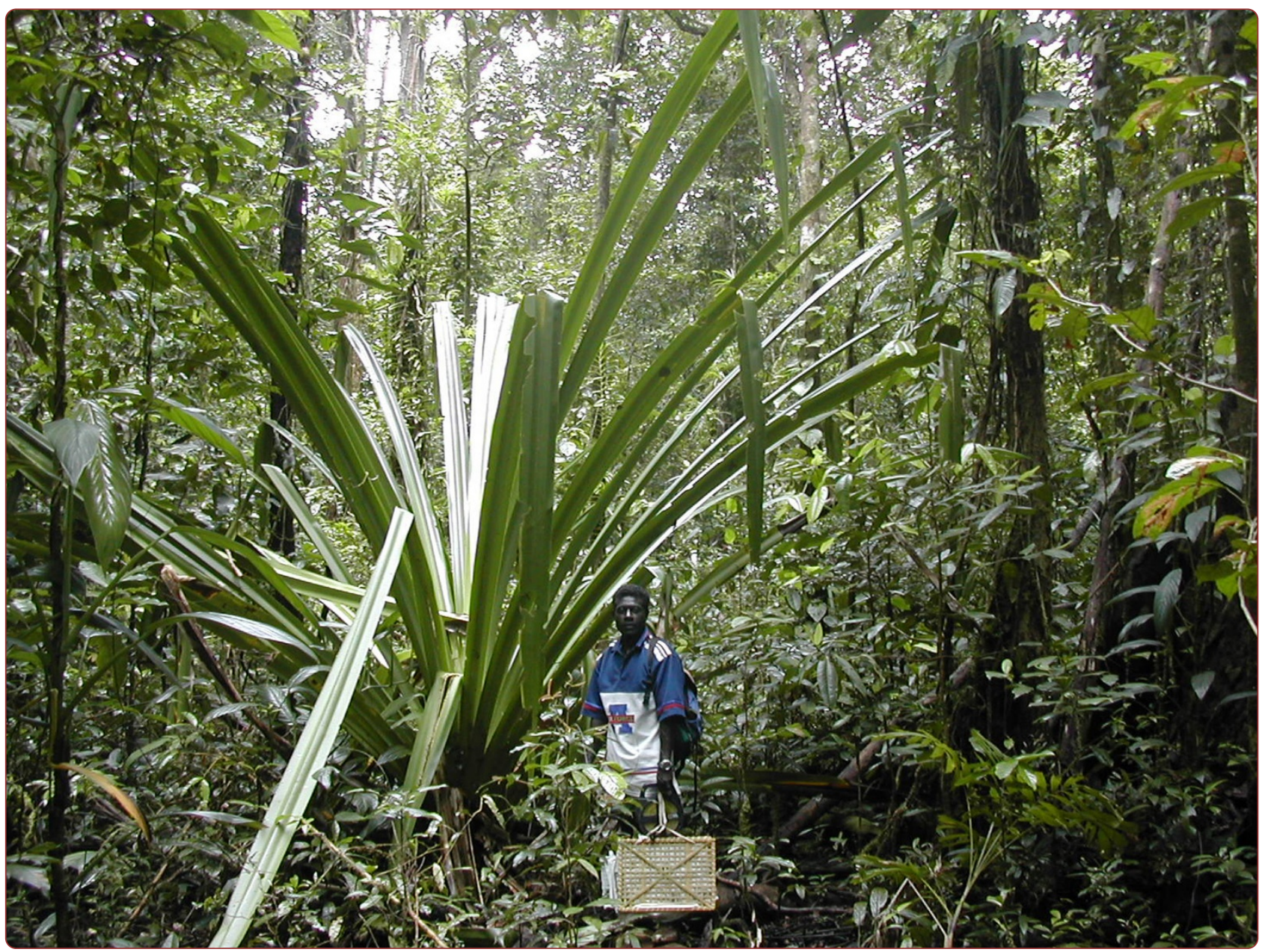

Interaction between forest biodiversity and people's use of forest resources in Roviana, Solomon Islands: implications for biocultural conservation under socioeconomic changes

Furusawa et al.

C Biomed Central 


\title{
Interaction between forest biodiversity and people's use of forest resources in Roviana, Solomon Islands: implications for biocultural conservation under socioeconomic changes
}

\author{
Takuro Furusawa ${ }^{1 *}$, Myknee Qusa Sirikolo², Masatoshi Sasaoka ${ }^{3}$ and Ryutaro Ohtsuka ${ }^{4}$
}

\begin{abstract}
Background: In Solomon Islands, forests have provided people with ecological services while being affected by human use and protection. This study used a quantitative ethnobotanical analysis to explore the society-forest interaction and its transformation in Roviana, Solomon Islands. We compared local plant and land uses between a rural village and urbanized village. Special attention was paid to how local people depend on biodiversity and how traditional human modifications of forest contribute to biodiversity conservation.

Methods: After defining locally recognized land-use classes, vegetation surveys were conducted in seven forest classes. For detailed observations of daily plant uses, 15 and 17 households were randomly selected in the rural and urban villages, respectively. We quantitatively documented the plant species that were used as food, medicine, building materials, and tools.

Results: The vegetation survey revealed that each local forest class represented a different vegetative community with relatively low similarity between communities. Although commercial logging operations and agriculture were both prohibited in the customary nature reserve, local people were allowed to cut down trees for their personal use and to take several types of non-timber forest products. Useful trees were found at high frequencies in the barrier island's primary forest (68.4\%) and the main island's reserve (68.3\%). Various useful tree species were found only in the reserve forest and seldom available in the urban village. In the rural village, customary governance and control over the use of forest resources by the local people still functioned.

Conclusions: Human modifications of the forest created unique vegetation communities, thus increasing biodiversity overall. Each type of forest had different species that varied in their levels of importance to the local subsistence lifestyle, and the villagers' behaviors, such as respect for forest reserves and the semidomestication of some species, contributed to conserving diversity. Urbanization threatened this human-forest interaction. Although the status of biodiversity in human-modified landscapes is not fully understood, this study suggested that traditional human modifications can positively affect biodiversity and that conservation programs should incorporate traditional uses of landscapes to be successful.
\end{abstract}

Keywords: Biocultural diversity, New Georgia Island, Quantitative ethnobotany, Roviana, Socioecological production landscape (SEPL), Traditional environmental knowledge (TEK), Solomon Islands

\footnotetext{
* Correspondence: takuro.f@gmail.com

'Graduate School of Asian and African Area Studies, Kyoto University, Room \#AA431, Research Bldg. No. 2, Yoshida-Honmachi, Sakyo-ku, Kyoto 606-8501, Japan

Full list of author information is available at the end of the article
} 


\section{Background}

Solomon Islands is a high-priority area for biodiversity conservation because of its location in the east Melanesian Islands biodiversity hotspot [1,2]. The rich biological diversity there stems from the fact that its more than 900 islands, covering $28,400 \mathrm{~km}^{2}$, have never been in land contact with the Asian continent or New Guinea Island, allowing a unique tropical rainforest flora and fauna to evolve [2]. The biodiversity is also perceived to be due to a lack of human intervention, but archaeological and forest ecological studies have indicated that the ecosystem is actually composed of many very old forests that had once been cleared by ancestral people in the Western Solomon Islands [3]. These societies, as with other societies in tropical rainforests, depended on forest ecosystem services for their traditional subsistence, including agriculture, the collection of natural resource products, fishing, and hunting $[4,5]$, and also had a spiritual connection to nature [6], and consequently learned to use the forest resources sustainably [7-9]. These traditional societies have often contributed to, rather than hindered, the creation and conservation of biodiversity, but such 'positive' human impacts are methodologically difficult to study and have often been neglected or undervalued in conservation programs.

Although various efforts have been made to record and analyze the biocultural diversity in Solomon Islands and other Melanesian and Southeast Asian societies [7-11], quantitative data are lacking. Recent studies and global initiatives (e.g., Convention on Biological Diversity) have highlighted the importance of integrating biodiversity conservation with the rights of indigenous people to use their ecosystems to improve their lifestyles [12-15]. In contrast, some top-down conservation decisions by agents outside of the communities have ignored local needs, causing disputes with local people and achieving limited success. Proponents have insisted that biodiversity conservation should aim to preserve sustainable human-modified natural environments, also called social-ecological production landscapes (SEPL), by encouraging broader global recognition of their value (e.g., Target 3 in Strategic Plan for Biodiversity 2011-20 and SATOYAMA Initiative in the 10th Meeting of the Convention of the Parties, Convention on Biological Diversity (CBD-COP10), 2010) [16-18]. Descriptive reports of such SEPLs $[6,14,17]$ have noted that forest consists of patches (including fallow forest and sacred forest) and that zoning of protected forest and agricultural land may decrease patch diversity [14].

Recently, several academic and non-governmental projects have worked to establish community-based nature conservation. In Solomon Islands, $87 \%$ of the land is classified as 'Customary Land' and is managed by traditional genealogical groups [19], so that rural communities themselves have autonomy over their forests. Consensus among the Customary Land members and integration of traditional ecological knowledge are recognized as key factors for successful conservation [20-22]. However, human impacts have recently increased in Solomon Islands, causing deterioration of biodiversity via population increases and socioeconomic globalization [5,23-25], e.g., by the expansion of agricultural lands, commercial logging, or the building of timber and oil palm plantations and urban infrastructure. The people's demand for commodities has increased with their recent exposure to Western culture and continues to increase rapidly. In addition, the export of natural resources has been a main source of cash income in the country, so control of resource development has been limited $[19,24,26]$. In urbanized areas, land disputes have hindered consensus for Customary Lands protection, allowing forest exploitation to continue [27]. To avoid overexploitation of forest resources, ecological services must satisfy the society's needs, and the society must recognize this to achieve consensus. However, how much ecosystem services were traditionally received by the people and what is lost to overexploitation is not clear.

In this study, we employed an ethnobotanical approach $[28,29]$ combined with vegetation surveys in two villages, one rural and one urbanized, to analyze the human-biodiversity relationships in the Western Solomon Islands. Our main objectives were to address: (1) how the people use different plant resources from forest and landscape diversity, (2) whether and how traditional ways of subsistence may have contributed to the creation and conservation of forest biodiversity, (3) how recent socioeconomic changes (i.e., urbanization) could impact this diversity, even in communities with autonomy over the forests, and (4) how biodiversity conservation programs can integrate local peoples' modifications of forests. This region of Solomon Islands is ideal for such a study because it has existed as a largely traditional society until recently and is still in the early stages of modernization. Special attention was paid to documenting the types of landscapes and how the behavior of the local people affected biodiversity. In addition, we studied how such interrelationships are affected by recent socioeconomic changes.

\section{Methods}

\section{Study sites}

This study was conducted in the Olive and Dunde villages in the Roviana region, Western Province, Solomon Islands (Figure 1). Roviana is located in the southwestern region of New Georgia Island and includes the nearby barrier islands, with an area extending $150 \mathrm{~km}$ from Koqu Kalena Bay to Munda. Almost all inhabitants in this area (pop. 14,805) speak the Roviana language and share the same ancestors and similar cultures, social institutions, and ecological conditions [30,31]. Munda, the 


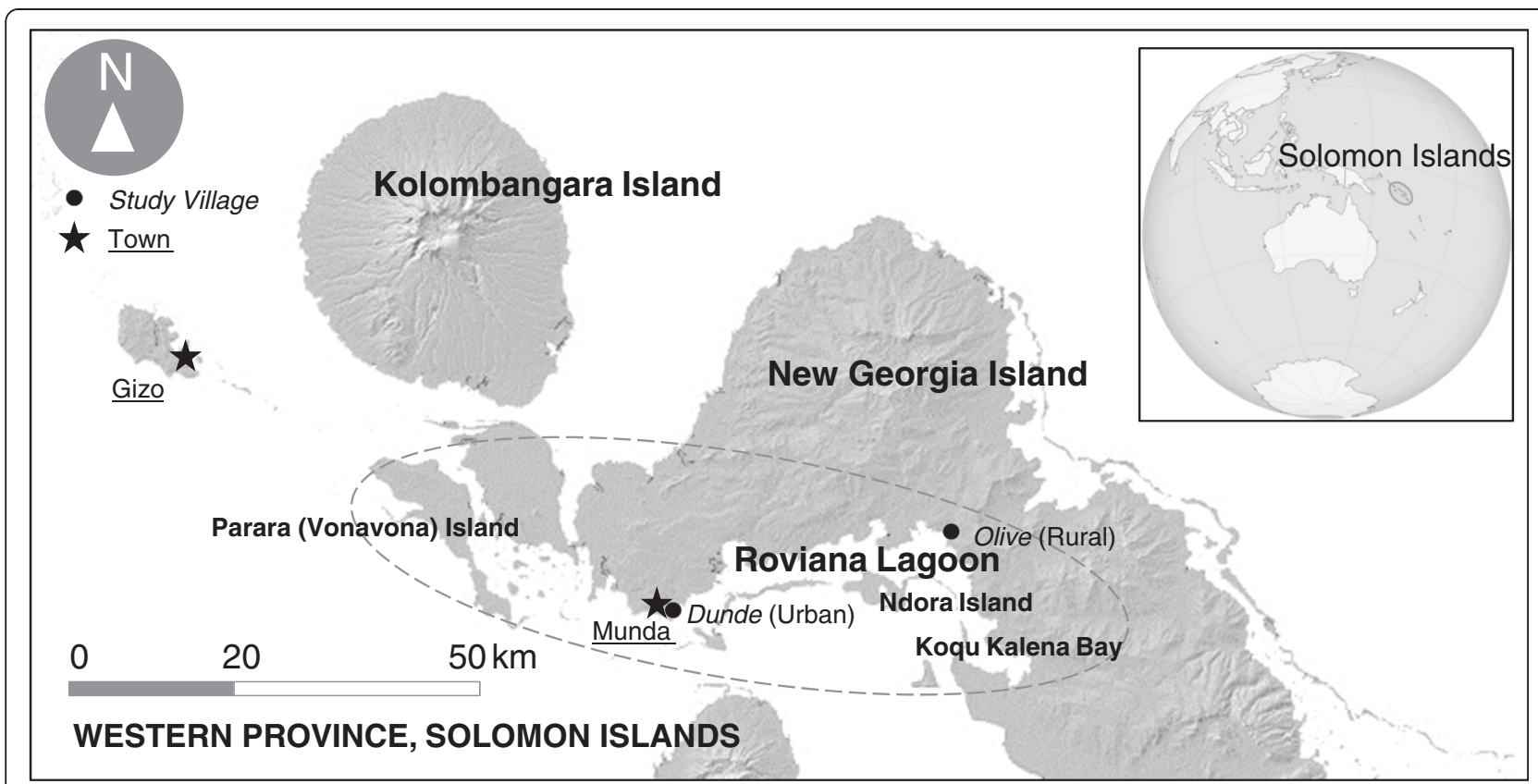

Figure 1 Locations of the study villages in the Roviana region, Solomon Islands. Map obtained from the USGS (2004). The global inset map was obtained from Wikipedia commons.

fourth largest town in the country, is a commercial center with governmental stations and several villages.

Dunde village, the largest settlement in the Munda area, was chosen as the urban study site. Olive village was chosen as the rural study site; it is one of the largest villages in the Saikile Customary Land and is approximately $32 \mathrm{~km}$ east of Munda, without roads or public transportation. The 'urban' Solomon Islanders are still very tied to their land base and often exhibit a degree of subsistence consumption, so that they are actually only semi-urban. Olive is much less affected by modern life. For instance, in Dunde with Olive, $86 \%$ and $28 \%$ of the houses are built in a modern style, $93 \%$ and $17 \%$ of households have rainwater tanks, $33 \%$ and $11 \%$ of households have outboard motors, and the average monthly household incomes are 1,752 SBD (Solomon Islands Dollars) and $378 \mathrm{SBD}$, respectively. However, there is a large amount of socioeconomic variation, especially in urban areas, as we reported elsewhere [32,33]; electricity and water lines are available only in Dunde. Regardless of these large economic differences, oral history and archaeological evidence suggest that the Dunde and Olive people are descended from a single ancestral population that migrated from Nusa Roviana Island, a small island located near Munda, in the late 18th or 19th century [34-36]. In addition, ecological conditions are similar throughout the Roviana region.

The most important form of subsistence agriculture in the Roviana region is the shifting cultivation of tuberous crops, in which lands are rotated between cultivation and fallow ground. We previously reported that this shifting cultivation is sustainable, with sufficient productivity to allow for an appropriate fallow period in Olive [25,33]. However, with Dunde's increased population and commercialization, the crop rotation cycles have been shortened, and the land has become unproductive [33]. Forest has also been used as a source of various kinds of resources, such as building materials, medicinal plants, and tools, and for magic/ritual purposes.

Since the arrival of the first Christian mission at the end of the 19th century, the Roviana people have gradually converted, and now almost all are Christian. However, traditional ways of thinking and behaving are still practiced in daily life. In addition, in Dunde, the coastal areas have been settled and converted to township functions; the construction of infrastructure began during the European colonial period (late 19th century) and accelerated during World War II, when both Japan and the United States built airfields and bases. Selective commercial logging began in the Western Province in the 1960s and in the Roviana Lagoon area in the 1980s $[19,37]$. In the Saikile Customary Land, areas near Olive village were logged in 1993-94. While the logging negatively affected the forest, the local people profited from employment, royalty payments, and improved infrastructure. The forests surrounding the Dunde area were not logged because the rights to those forests were violently disputed within and among communities and clans [27]. However, the people have been economically affected by logging operations in nearby areas (e.g., Vonavona, 
Enoghae) since the 1960s through employment and royalty payments. One of the authors (TF) has lived in Roviana for a total of approximately 2 years since 2001, speaks the local Roviana language, understands the local customs and culture, and has built a rapport with the people [25,32,33,37,38].

\section{Local landscape interviews}

The authors (TF, MS, and RO) walked throughout the territorial forests, gardens, plantations, and other subsistence lands. During this participatory observation, we classified the landscape. Forest ecological and floristic surveys [39] and plant resource surveys [4] of the whole Solomon Islands are helpful to understand the landscape and vegetation, and ethnoecological studies in the neighboring Marovo region are also informative $[5,40]$. In addition, brief descriptions of the Roviana landscape are available [41]. However, this information was not sufficient to describe the human-forest relationships, so we evaluated the landscape and vegetation of the study sites using the following methods.

Locally recognized land-use classes were identified through interviews with four local elders who had been recommended as forest experts by a committee of leaders. The authors visited various locations with these experts, who identified local Roviana names for different land use classes, including a variety of forested classes (hereafter called 'forest classes'). In our protocol, any disagreements were to be resolved by discussion among the experts, authors, and other villagers, although such disagreements rarely happened. The ecological characteristics of 12 land-use classes on New Georgia Island were also determined during these interviews (Figure 2). Four of the 12 land use classes were found on the barrier islands (e.g., Ndora Island, an extension of Olive). The villagers used terms tutupeka and toba for the geographic characteristics of New Georgia Island and the barrier islands, respectively. TF observed and participated in various subsistence activities and confirmed that these classes were widely recognized and frequently referenced in daily life; although the number of experts (4) was small, the classifications reflected widespread recognition by the villagers.

\section{Vegetation surveys}

Quadrat vegetation surveys were conducted in seven forest classes: (1) primary forest (muqe) on the main island, (2) primary forest on the barrier island, (3) secondary forest (nobo, 15-year-old fallow land) on the main island, (4) secondary forest (15-year-old fallow land) on the barrier island, (5) reserve forest (rizevu) on the main island, (6) selectively and commercially logged forest (originally primary forest; 8-9 years after operation) on the main island, and (7) mangrove forest (petupetuana). Freshwater swamp forest (zemizemi) and coastal vegetation were also surveyed but not analyzed in this study. The ancestor's secondary forest (emata) and sacred forest (hope) were excluded from the survey because these classes, existing as patches in primary or secondary forests, were small or difficult to distinguish independently of the experts. Settlement vegetation (popoa/vasileana) was also excluded because of the logistic challenges to establishing quadrats in privately-managed plots.

Four $25 \times 25-\mathrm{m}$ quadrats were established in each forest class. i.e., 0.25 ha in total per class. Small plots can been problematic in vegetation surveys, but 0.25 ha quadrats or smaller have been used successfully when locally-defined forest types were not extensive enough to establish larger plots [42]. Because the local people near the rural village recognized two separate areas as reserve forests, four quadrats were established in each of these two forests: i.e., 0.5 ha in total for this class only. For the statistical analysis, the number of trees counted in the reserve forests was divided in half so that all forest types were comparable. The vegetation surveys were conducted in the territory of the Saikile Customary Land.

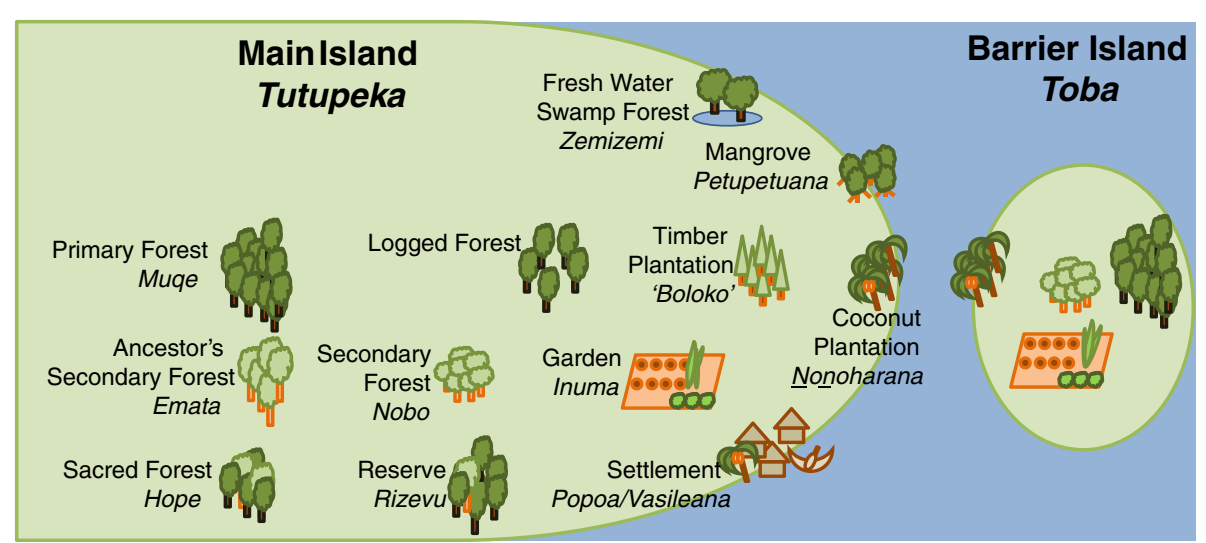

Figure 2 Forest and land use classifications in the local Roviana language. 
All trees $>10 \mathrm{~cm}$ in DBH (diameter at breast height) were counted and identified with the local Roviana name by the experts. If the experts did not know or could not agree on a name, the plant was listed as 'unknown'. Botanical specimens were collected, stored in liquid alcohol in the field, and later dried at Munda Forestry Station, Ministry of Forestry of the Solomon Islands Government.

\section{Plant use observations}

For detailed observations of plant use, 15 and 17 households were randomly selected from the 64 and 206 households in Olive and Dunde, respectively. Written informed consent for participation in the survey was obtained from each head-of-household (head). The participants were informed that they could withdraw from the study at any time and that they had a right to refuse to answer any questions. All interviews were conducted in the local Roviana language by TF with the help of local assistants (Mr. Edwin Huti and Mr. Rex Daga). No economic incentives were provided to the participant households to avoid bias; however, following the completion of the research, a suitable cultural gift (food) was given to each household.

\section{Food}

All foods consumed in each study household during a 1 -week period were observed and their weights were recorded every 80-90 minutes from 7:00 a.m. to 8:208:30 p.m. every day. When a participant ate food outside the village, the diet information was obtained through an interview. The energy (MJ) contribution of the plants was estimated using measurements and interviews in tandem with food composition tables $[43,44]$. The food surveys were conducted in August in both villages to avoid seasonal differences between the two villages.

\section{Building materials}

TF visited every household and asked the head and/or builder to provide the local Roviana name for each material used during construction, i.e., the names of the materials used for floors, walls, poles, rafters, beams, roofs, and other parts of the houses.

\section{Medicine}

Each household was visited daily, and the head and/or spouse were asked to report any illnesses and describe the treatments, including medicinal plants, used in that household every evening for 28 days. When the patient consulted other villagers or herbalists outside of the village, the herbalist was interviewed about the recipe. If the herbalist refused to disclose his/her recipe, that treatment was excluded from the analysis. We tallied the total number of ill person-days and the numbers of ill person-days on which traditional and Western medicines were used. On some days, the ill person used both traditional and Western treatments.

\section{Tools}

Tools made from plants were observed and surveyed in interviews. First, the head and/or spouse were asked to list all plant-made tools owned. A single, village-wide list of tools was compiled by visiting each household in turn. Then, each household was visited again, and the heads/ spouses were asked what materials were used for each item on the final list (27 types of tools). Note that any plants used for rituals and magic, which are now rarely observed, were categorized as tools.

\section{Botanical name identification}

As described above, the forest experts identified the local Roviana names of plants found during the vegetation surveys, and the household heads, adult members, and/ or house builders identified the names of plants used for food, building materials, medicines, or tools. Living plant specimens were shown to the interviewees during the household surveys, if necessary. Botanical specimens were collected in the field, and one of the authors (MQS) identified the scientific names at the Poitete Institute of Forestry, Western Province, Solomon Islands. The local Roviana names were used as species designations in analyses to connect the vegetation and plant use data, although, in some cases, the villagers recognized two or more taxonomic species as one Roviana vernacular name or vice versa. English names were used for convenience.

\section{Statistical analysis}

The similarity of species composition between each pair of forest classes was calculated using the Sørensen-Dice similarity index:

Sorensen-Dice similarity index $(\%)=2 c /(a+b) \times 100 \%$

where $c$ is the number of species observed in both forest classes and $a$ and $b$ are the number of species in forest classes A and B, respectively. This index is useful for assessing ecological community data and is sensitive to heterogeneous data [45]. The proportions of useful trees in each vegetation quadrat were used to compare plant use in Dunde and Olive using the $X$-square test. All statistical analyses were performed using the $R$ version 2.15 ( $\mathrm{R}$ Foundation for Statistical Computing, Vienna, Austria).

\section{Results}

\section{Folk landscape and vegetation}

Figure 2 shows the vegetation and land use classes recognized by the local people. The local people call the geographic setting of New Georgia Island tutupeka and that of the barrier islands toba. In their understanding 
and in the results of scientific surveys [27], the barrier island's soil and vegetation are different from those of the main island. Land systems in New Georgia are characterized by dominant canopy species, such as Calophyllum vitiense Turr., C. kajewskii A. C. Smith, Dillenia spp.. and Campnosperma brevipetiolata Volk. in lowland forests and Terminalia brassii Ewell. in swamps, while the barrier islands are dominated by Pometia pinnata J. R. Forst. and G. Forst. and Vitex cofassus Reinw. ex Blume.

Primary forests-i.e., those recognized as being unmodified by humans-are called muqe. In reality, the muqe are used by the people to collect non-timber forest materials or to hunt wild pigs and are not pristine but rather experience human-forest interactions. In addition, Bayliss-Smith et al. [3] reported that 'primary' forests on New Georgia Island may actually include sites of former settlements, forest clearings, and agriculture (irrigated taro terraces called ruta).

One type of old secondary forest is called emata. This forest type is called an ancestor's secondary forest because it was deforested and abandoned before the current people were born. According to the interviewees, some gigantic trees with high customary value, such as Canarium salomonense B. L. Burtt, are characteristic in such forests. The emata is sometimes recognized as providing evidence of their ancestor's customary ownership of that land $[5,35,36]$. Meanwhile, forest areas previously inhabited by ancestors or used for rituals are now considered shrinescalled hope-and entry and tree felling are prohibited there. The people believe that trespassers will be punished by supernatural powers (tomate). These sacred forests represent an aspect of the people's customary land management.

Fallow or secondary forests that had been abandoned after shifting cultivation are called nobo. According to the interviewees, the residents gather medicinal plants and small trees and palms for building houses in the nobo. In our vegetation surveys, the secondary forest was characterized by a number of Macaranga tree species. In addition, on the main island, the existence of several Commersonia bartramia (L.) Merr. and a pioneer species, white beech (Gmelina moluccana Backer ex K. Heyne), was characteristic. On the barrier islands, Syzygium spp. and Flueggea flexuosa Müll. Arg. were common.

Logged forest is now a prevalent type of forest on New Georgia Island, although it has no Roviana name. The major target is upper canopy species with commercial value, such as Calophyllum spp., P. pinnata, Dillenia salomonensis (C. T. White) Hoogl., Terminalia brassii Exell, and $V$. cofassus. Some species, such as white beech, are protected by agreements between the local people and logging companies. In addition, felling trees of $<60 \mathrm{~cm}$ DBH is prohibited by forestry acts, as is logging near rivers or flowing streams and on steep hills.
Although reforestation for timber plantations commenced in the 1990s, this activity intensified in the 2000s $[37,46]$. The logged forest was clear cut to create lands for timber plantations. Such community-level reforestation has accelerated under the leadership of one of the largest church groups (Christian Fellowship Church: CFC) in New Georgia Island. Teak (Tectona grandis L. f.) and rainbow eucalyptus (Eucalyptus deglupta Blume) are common plantation species. In addition, oil palm (Elaeis guineensis Jacq.) plantations have expanded in the northern part of New Georgia but only to a limited extent in Roviana during the study period. Although large-scale logging operations are not conducted in the urban territory, expectations of future cash income have driven the people to clear-cut the secondary forest for timber plantations.

There are reserve forests called rizevu (borrowed from the English word 'reserve') near the rural village. These nature reserves were established in accordance with the recommendations of local chiefs and CFC leaders. Although logging by multinational companies and agricultural cultivation are both prohibited in these areas, the local people are allowed to cut down trees for their personal use and to remove several non-timber forest products. The vegetation in these reserve forests differs from that in both primary and secondary forests because of continuous anthropogenic impacts. These forests are characterized by a mixture of climax (C. kajewskii) and pioneer (Palaquium erythrospermum H. J. Lam., Garcinia celebica L., Elaeocarpus floribundus Blume, and C. brevipetiolata) species. The reserve forests are found in the rural, not urban, areas.

Mangroves (petupetuana) provide not only plant resources but also hunting grounds for shellfish and crabs and are important to the rural people. For example, the interviewees insisted that a group of people once protested and forced a logging company to halt operations when an inflow of red soil decreased the populations of shellfish and crabs. The dominant species is Bruguiera gymnorhiza (L.) Lam., followed by Rhizophora apiculata Blume. In contrast, mangroves are quite rare in urban villages because the coastal area has been converted to infrastructure and settlements.

The primary crops are sweet potatoes (Ipomoea batatas (L.) Lam.) and cassavas (Manihot esculenta Crantz); traditional tuberous crops, such as taro (Colocasia esculenta (L.) Schott) and yams (Dioscorea spp.), are also planted in approximately half of the gardens. Non-edible plants, such as Coleus spp., are also planted for decoration or magic (e.g., protecting crops from pest animals) in gardens. Settlements are called popoa or vasileana. Almost all trees and palms that grow in the settlements were either domesticated or semidomesticated and used for various purposes. For instance, all trees of $>10 \mathrm{~cm}$ 
$\mathrm{DBH}$ found along a road in Olive village were either coconut (Cocos nucifera L.), betel nut (Areca catechu L.), cut nut (Barringtonia procera (Miers) R. Knuth), tropical almond (Terminalia catappa L.), or kapok (Ceiba pentandra (L.) Gaertn. and Bombax malabaricum DC.). Introduced flowering plants, such as Catharanthus roseus (L.) G. Don., were planted in some houses for ornamental purposes.

\section{Plants used in daily life \\ Plants used for food}

Based on the household survey, 149 species were used for food, medicine, building materials, or tools during the study period; (a list of all plants used is available as Table 1) 39 of these species were used as food. Sweet potato and cassava were the primary sources of energy in both villages $(38.7 \%$ and $18.3 \%$ in the rural and urban villages, respectively). Six representative tree or palm species that provided the next highest levels of energy are shown in Table 2. Coconut contributed to approximately $4 \%$ of the total energy intake in both villages. Canarium nuts (Canarium indicum L. and $C$. salomonense) amounted for $3.3 \%$ of energy intake in the rural area but only $0.1 \%$ of energy intake in the urban area. While most of the food plants were cultivated or planted in gardens, gnetum tree (Gnetum gnemon L.) grew in nobo secondary forest; the people did not always plant this tree but usually refrained from weeding/ hurting it under semidomesticated conditions (i.e., they have not been fully domesticated but are protected by the people in the wild and near settlements or gardens $[36,37])$. Fruits were collected from wild large-leafed mangrove (B. gymnorhiza (L.) Lam.).

\section{Plants used to treat illnesses}

Herbal medicines were used in $14.5 \%$ and $25.4 \%$ of treatments for ill person-days, accounting for 159 and 201 cases in the urban and rural areas, respectively. Nineteen species were used on 112 person-days in the villages combined. Coconut oil, used on 30 person-days to treat wounds and skin conditions or for pain relief massage, was the most common herbal treatment. Coconut oil mixed with oil extracted from ylang-ylang (Cananga odorata (Lam.) Hook. f. \& Thomson) was used on 25 person-days. Rose periwinkle (Catharanthus roseus (L.) G. Don), which was recently introduced as a flowering and ornamental plant in urban areas, was used on 16 person-days for diabetes; no Roviana name was recognized for this plant. Heartleaf hempvine (Mikania cordata (Burm. f.) B. L. Rob.) was used to treat wounds. Table 3 shows representative tree or palm species used for treatment. In addition to coconut palm and ylangylang, three species (tropical almond, betel-nut palm (Areca catechu L.), and great morinda (Morinda citrifolia L.)) were used for $2.0 \%$ or $2.5 \%$ of total ill person-days in the two villages, respectively. More medicinal species were used in the rural areas. Almost all herbal plants were planted in the settlements or grown under semidomesticated conditions in secondary growth nearby. Tropical almond and Cassia alata L. (not in the table) are representative semidomesticated species.

\section{Plants used to build houses}

Plants used as building materials comprised 71 species, including trees, palms (including rattan), and bamboo. Table 4 shows the 11 species most frequently used by the households in both villages. The two most frequently used species were Calophyllum spp. (100\% in each village) and $V$. cofassus (100\% and $88.2 \%$ in the rural and urban villages, respectively). These trees were too large for the rural people to fell by themselves without chainsaws; therefore, the villagers frequently purchased sawn timber from the logging company campsites. Low prices are available for low-grade timber in the local market. Sago palm (Metroxylon spp.) leaves were the major materials for walls and roofs in traditional leaf houses; the palm leaves were tightened with thin sticks made from local areca-nut palm trunks (Areca macrocalyx Zipp. ex Blume). Rattan palms (Calamus spp.) were used as ropes to tighten joints and many other parts of the houses; iron nails were rarely used in building traditional leaf houses. Even many households living in permanent houses had small kitchen huts in which rattan was used (93.3\% and $82.4 \%$ in the rural and urban villages, respectively). The medium-sized flueggea tree ( $F$. flexuosa) was a major source of posts used to build leaf houses; therefore, this tree was used more in the rural village than in the urban village ( $93.3 \%$ and $70.6 \%$, respectively). This tree was used in a round-log form after removal of its bark. Fijian longan (P. pinnata) was frequently used in the urban village $(94.1 \%)$ and rarely used in the rural one (20.0\%). Logs from this tree were produced at the logging campsites and traded in this area; this large tree is grown primarily on the barrier islands. Since logging operations had been prohibited on the barrier islands of the Saikile clan until recently, the timbers of this tree were rarely used in the rural village. Large-leafed mangroves (B. gymnorhiza (L.) Lam.), which were more abundant in the rural areas, were more frequently used in the rural village $(66.7 \%)$ than in the urban village (47.1\%). Trees that were abundant in secondary growth (brown kurrajong (C. bartramia) and D. salomonensis) comprised materials for building leaf houses and were used exclusively in the rural village.

\section{Plants used for tools}

Among the various daily commodities, 27 tools were made from 53 species of plants. Table 5 shows the 13 
Table 1 List of plants used in the Roviana, sorted alphabetically by the Roviana name, with use purposes observed

\begin{tabular}{|c|c|c|c|c|c|}
\hline Roviana name & Scientific name & Family & Plant type ${ }^{a}$ & Use purpose ${ }^{b}$ & Forest class $^{c}$ \\
\hline Agana & Pandanus spp. & Pandanaceae & $\mathrm{pl} / \mathrm{tr}$ & $\mathrm{T}$ & MM \\
\hline Agana pinomo & Pandanus sp. & Pandanaceae & $\mathrm{pl} / \mathrm{tr}$ & $\mathrm{T}$ & \\
\hline Aroso & Calamus spp. & Arecaceae & $\mathrm{cl} / \mathrm{pl}$ & $B, T$ & \\
\hline Aroso inoko & Calamus sp. & Arecaceae & $\mathrm{cl} / \mathrm{pl}$ & B & \\
\hline Asama & Lygodium spp. & Schizaeaceae & $\mathrm{fn} / \mathrm{cl}$ & $\mathrm{T}$ & \\
\hline Babageva masa & Heritiera littoralis Ait. & Sterculiaceae & $\operatorname{tr}$ & $\mathrm{T}$ & $M R, M M$ \\
\hline Balusa & Ochroma pyramidale Urb. & Bombacaceae & $\operatorname{tr}-1$ & $\mathrm{~T}$ & \\
\hline Bebea & Tournefortia argentea L. & Boraginaceae & sh & T & \\
\hline Bekoto & Various small palms & Arecaceae & $\mathrm{pl}$ & B & \\
\hline Beti & Bambusa spp. & Poaceae & $\mathrm{gr} / \mathrm{tr}-\mathrm{s}$ & $B, T$ & \\
\hline Binisi & Phaseolus vulgaris L. & Fabaceae & $\mathrm{hb}$ & $\mathrm{F}$ & \\
\hline Binisi noki & Trichosanthes cucumerina $\mathrm{L}$. & Cucurbitaceae & $\mathrm{hb} / \mathrm{cl}$ & $\mathrm{F}$ & \\
\hline Bobogele & Pemphis acidula J.R. \& G. Forst. & Lythrales & sh/tr-s & $B, T$ & \\
\hline Bobopa & Epipremnum sp. & Araceae & $\mathrm{Cl}$ & M & \\
\hline Bolava & Haplolobus canarioides Leenh. & Burseraceae & $\operatorname{tr}$ & B & $M P, M R, M L$ \\
\hline Bosi & Euodia salomonensis Merr. \& Perry & Rutaceae & tr & B & $M R, M S, B S$ \\
\hline Bosi suka & Euodia elleryana Muell. & Rutaceae & $\operatorname{tr}$ & B & MR, MS \\
\hline Bou & Fagraea gracilipes A. Gray & Rubiaceae & $\operatorname{tr}$ & $B, T$ & \\
\hline Buni & Calophyllum spp. & Clusiaceae & $\operatorname{tr}$ & $B, T$ & $M P, M R, M L$ \\
\hline Dadao & Barringtonia asiatica (L.) Kurz & Lecythidaceae & tr & T & \\
\hline Dalou & Pandanus sp. & Pandanaceae & $\mathrm{pl} / \mathrm{tr}$ & $\mathrm{T}$ & \\
\hline Deri & Citrullus lanatus (Thunb.) Mansf. & Cucurbitaceae & $\mathrm{hb} / \mathrm{cr}$ & $\mathrm{F}$ & \\
\hline Dikidiki & Dioscorea esculenta (Lour.) Burk. & Dioscoreaceae & $\mathrm{hb} / \mathrm{cl}$ & $\mathrm{F}$ & \\
\hline Dodoru & Trema orientalis (L.) Bl. & Ulmaceae & tr & B & MS \\
\hline Domu & Unidentified & & $\operatorname{tr}$ & B & \\
\hline Edeve & Metroxylon spp. & Arecaceae & $\mathrm{pl}$ & $(F), B, T$ & \\
\hline Eehara & Horsfieldia spicata (Roxb.) Sinclair & Myristicaceae & $\operatorname{tr}$ & B & $M P, M R, M L, B P, B S$ \\
\hline Egipalanti & Solanum melongena $\mathrm{L}$. & Solanaceae & $\mathrm{hb} / \mathrm{sh}$ & $\mathrm{F}$ & \\
\hline Elelo bakua & Cassia alata $\mathrm{L}$. & Caesalpiniaceae & sh & M & \\
\hline Elohilu & Unidentified & & tr & B & \\
\hline Gaekubo & Garcinia celebica L., G. solomonensis A.C. Sm. & Clusiaceae & tr & B & $\mathrm{MP}, \mathrm{MR}, \mathrm{MS}, \mathrm{ML}$ \\
\hline Geholo & $\begin{array}{l}\text { Schleinitzia novo-guineensis (Warb.) } \\
\text { Verdc. }\end{array}$ & Leguminoceae & $\operatorname{tr}-\mathrm{s}$ & B & \\
\hline Gozigolo & Scindapsus altissimus V.A.V.R. & Araceae & $\mathrm{cl}$ & $\mathrm{T}$ & \\
\hline Guava & Psidium guajava L. & Myrtaceae & tr-s & $F, T$ & \\
\hline Gurata & Morinda citrifolia L. & Rubiaceae & $\operatorname{tr}-\mathrm{s}$ & M & \\
\hline Habe & Unidentified & & & T & \\
\hline Haila & Syzygium sp. & Myrtaceae & $\operatorname{tr}$ & $\mathrm{T}$ & $\mathrm{BP}$ \\
\hline Hakua & Musa spp. & Musaceae & $\mathrm{hb} / \mathrm{tr}-\mathrm{s}$ & $\mathrm{F}$ & \\
\hline Halagire & Pandanaceae & & & $\mathrm{T}$ & BS \\
\hline Hame & $\begin{array}{l}\text { Calophyllum paludosum C.T. White., C. } \\
\text { neo-ebudicum Guill. }\end{array}$ & Clusiaceae & $\operatorname{tr}$ & B & $\mathrm{MR}$ \\
\hline Harekete & $\begin{array}{l}\text { Microsorium scolopendria (Burm. f.) } \\
\text { Copel. }\end{array}$ & Polypodiaceae & $\mathrm{fn} / \mathrm{cl}$ & M & \\
\hline
\end{tabular}


Table 1 List of plants used in the Roviana, sorted alphabetically by the Roviana name, with use purposes observed (Continued)

\begin{tabular}{|c|c|c|c|c|c|}
\hline Hebere & Dillenia ingens Burtt & Dilleniaceae & tr-1 & $B$ & $M R, M S, M L$ \\
\hline $\begin{array}{l}\text { Heta (heta } \\
\text { manavasa) }\end{array}$ & Areca catechu L. & Arecaceae & $\mathrm{pl}$ & $F, M, B$ & \\
\hline Heta pinomo & Areca macrocalyx Zipp. Ex BI. & Arecaceae & $\mathrm{pl}$ & $(F), B$ & \\
\hline Hioko & Syzygium sp. & Myrtaceae & $\operatorname{tr}$ & B & $M P, M R, M S, B P, B S$ \\
\hline Hipahipala & Syzygium sp. & Myrtaceae & $\operatorname{tr}$ & B & \\
\hline Horehore & Calophyllum sp. & Clusiaceae & $\mathrm{tr} / \mathrm{tr}-\mathrm{l}$ & B & $M P, M R, M S, M L$ \\
\hline Hovaka & Burckella obovata (Forst.) Pierre & Sapotaceae & $\operatorname{tr}-1$ & $\mathrm{~B}, \mathrm{~T}$ & \\
\hline Igisi & Piper betle $\mathrm{L}$. & Piperaceae & $\mathrm{sh} / \mathrm{cl}$ & $F, M$ & \\
\hline Ika pengi & Unidentified & & & B & \\
\hline Ivili & Intsia bijuga (Colebr.) Kuntze & Caesalpiniaceae & tr-m & $B, T$ & \\
\hline Kabisi & Brassica chinensis $\mathrm{L}$. & Cruciferae & hb & $\mathrm{F}$ & \\
\hline Kakarumu & Lumnitzera littorea (Jack.) Voigt & Combretaceae & tr-s & $B, T$ & \\
\hline Kanana & $\begin{array}{l}\text { Gulubia macrospadix (Burret) H.E. } \\
\text { Moore }\end{array}$ & Arecaceae & $\mathrm{pl}$ & B & $M P, M R, M S, M L$ \\
\hline Kapuhu & $\begin{array}{l}\text { Dillenia salomonensis (C.T. White) } \\
\text { Hoogl. }\end{array}$ & Dilleniaceae & $\operatorname{tr}$ & $\mathrm{B}, \mathrm{T}$ & MRML \\
\hline Karuvera & Alocacia macrorrhiza (L.) G. Don & Araceae & hb & & \\
\hline Keto & Zea mays L. & Poaceae & $\mathrm{gr} / \mathrm{hb}$ & $\mathrm{F}$ & \\
\hline Kikilapa (kilala) & Ochroma pyramidale Urb. & Bombaceae & tr-I & T & \\
\hline Kinu & Barringtonia procera (Miers) R.Knuth & Lecythidaceae & $\operatorname{tr}$ & F & \\
\hline Kokeqolo & Aglaia brassii Merr. and Perry & Meliaceae & $\operatorname{tr}$ & B & $M P, M R, M L, B P, B S$ \\
\hline Kosikosiri & Diplazium esculentum (Retz.) Sw. & Athyriaceae & fn & $\mathrm{F}$ & \\
\hline Kukaba & Cucumis sativus $\mathrm{L}$. & Cucurbitaceae & $\mathrm{hb} / \mathrm{cl}$ & $\mathrm{F}$ & \\
\hline Kureu & Diospyros ferrea (Willd.) Bakh. & Ebenaceae & tr-s & B & $M P, M R$ \\
\hline Laini & Citrus aurantifolia (Christm.) Swing. & Rutaceae & tr-s & $F, M$ & \\
\hline Lemone & Citrus limon (L.) Burm. f. & Rutaceae & tr-s & $(F), M$ & \\
\hline Leqe & Gnetum gnemon L. & Gnetaceae & $\operatorname{tr}$ & $\mathrm{F}$ & BS \\
\hline Levaleva & Unidentified & & $\operatorname{tr}$ & B & $\mathrm{ML}$ \\
\hline Likisi & Allium porrum L. & Liliaceae & hb & $\mathrm{F}$ & \\
\hline Liqelige & Unidentified & & $\operatorname{tr}$ & B & $M L, B P$ \\
\hline Lozi & $\begin{array}{l}\text { Ceiba pentandra (L.) Gaertn., Bombax } \\
\text { malabaricum DC. }\end{array}$ & Bombaceae & tr-m & T & \\
\hline Lulua & Amoora cucullata Roxb. & Meliaceae & $\operatorname{tr}$ & B & $M P, M R, B P, B S$ \\
\hline Luluzu & Mikania cordata (Burm. f.) B.L. Rob. & Asteraceae & $\mathrm{hb} / \mathrm{cl}$ & M & \\
\hline Luzu vaka & Ipomoea batatas (L.) Lamk. & Convolvulaceae & $\mathrm{hb} / \mathrm{cr}$ & $F, M$ & \\
\hline Mahigeli & Gulubia hombronii Becc. & Arecaceae & $\mathrm{pl}$ & B & \\
\hline Manioko & Carica papaya L. & Caricaceae & $\operatorname{tr}$ & $\mathrm{F}$ & \\
\hline Marihi & Dioscorea spp. & Dioscoreaceae & $\mathrm{hb} / \mathrm{cl}$ & $\mathrm{F}$ & \\
\hline Mavuana & Flueggea flexuosa Müll.Arg. & Euphorbiaceae & $\operatorname{tr}$ & $B, T$ & BS \\
\hline Mokulou & Unidentified & & $\operatorname{tr}$ & B & \\
\hline Naqarita & $\begin{array}{l}\text { Cananga odorata (Lamk.) Hook. f. \& } \\
\text { Thoms. }\end{array}$ & Annonaceae & tr-m & $M, T$ & \\
\hline Naru & Casuarina equisetifolia J.R. \& G. Forst. & Casuarinaceae & tr-m & T & \\
\hline Natono & Rhus taitensis Guill. & Anacardiaceae & $\operatorname{tr}$ & $B, T$ & MS \\
\hline Neka & Hibiscus manihot L. & Malvaceae & sh & $\mathrm{F}$ & \\
\hline
\end{tabular}


Table 1 List of plants used in the Roviana, sorted alphabetically by the Roviana name, with use purposes observed (Continued)

\begin{tabular}{|c|c|c|c|c|c|}
\hline Nekete & Pipturus argenteus (Forst. f.) Wedd. & Urticuliaceae & sh/tr-s & M & \\
\hline Nobinobi ime & Unidentified & Fabaceae & & T & \\
\hline Nohara & Cocos nucifera $\mathrm{L}$. & Arecaceae & $\mathrm{pl} / \mathrm{tr}-\mathrm{m}$ & $F, M, B, T$ & MM \\
\hline Nonoqara & Nephrolepis hirsutula (Forst.) Presl & Oleandraceae & fn & T & \\
\hline Okete & Canarium indicum L. & Burseraceae & tr-m & $\mathrm{F}$ & \\
\hline Okokete & $\begin{array}{l}\text { Garuga floribunda Dence., Canarium } \\
\text { vitiense A. Grat }\end{array}$ & Burseraceae & $\mathrm{tr} / \mathrm{tr}-\mathrm{m}$ & B & MR, MS \\
\hline Onioni & Allium cepa L. var. aggregatum G. Don & Amaryllidaceae & hb & F & \\
\hline Opiti & $\begin{array}{l}\text { Spondias dulcis Sol. ex Parlk., Averrhoa } \\
\text { carambola L. }\end{array}$ & & & $\mathrm{F}$ & \\
\hline Ore marihi & Manihot esculenta Crantz & Euphorbiaceae & sh & $\mathrm{F}$ & \\
\hline Paenapo & Ananas comosus (L.) Merr. & Bromeliaceae & $\mathrm{hb}$ & $\mathrm{F}$ & \\
\hline Paloto & Palaquium erythrospermum Lamk. & Sapotaceae & $\operatorname{tr}$ & B & $M R, M L$ \\
\hline Pamukeni & $\begin{array}{l}\text { Cucurbita moschata (Duch. ex Lamk.) } \\
\text { Duch. ex Poir }\end{array}$ & Cucurbitaceae & $\mathrm{hb} / \mathrm{cl}$ & $\mathrm{F}$ & \\
\hline Pate & Pandanus tectorius Park. & Pandanaceae & $\mathrm{pl} / \mathrm{tr}$ & T & \\
\hline Pepa & $\begin{array}{l}\text { Capsicum annum L. var. grossum } \\
\text { Sendt. }\end{array}$ & Solanaceae & $\mathrm{hb}$ & $\mathrm{F}$ & \\
\hline Pepeo & Terminalia brassii Exell & Combretaceae & $\operatorname{tr}-1$ & B & \\
\hline Petepete & Litsea domarensis Schmidt & Lauraceae & $\operatorname{tr}$ & B & MS, ML \\
\hline Petu & Bruguiera gymnorhiza (L.) Lam. & Rhizophoraceae & $\operatorname{tr}$ & $F, B, T$ & MM \\
\hline Petukele & Macaranga fimbriata S. Moore & Euphorbiaceae & $\operatorname{tr}$ & B & \\
\hline Pidiki & Syzygium onesimum Merr. \& Perry & Myrtaceae & $\operatorname{tr}$ & $\mathrm{B}, \mathrm{T}$ & $M P, M R, M L, B P$ \\
\hline Pilasi & Unidentified & & & $\mathrm{T}$ & \\
\hline Pinati & Arachis hypogaea L. & Fabaceae & $\mathrm{hb}$ & $\mathrm{F}$ & \\
\hline Pokopoko & Campnosperma brevipetiolata Volkens & Anacardiaceae & $\operatorname{tr}-\mathrm{I}$ & $\mathrm{B}, \mathrm{T}$ & $M R, M L$ \\
\hline Pomolo & Citrus grandis (L.) Osbeck & Rubiaceae & tr-s & $\mathrm{F}$ & \\
\hline Qema & Pometia pinnata Forst. f. & Sapindaceae & tr-m & $\mathrm{B}, \mathrm{T}$ & $M R, M S, B P$ \\
\hline Qoliti & Gmelina moluccana Backer ex K.Heyne & Verbenaceae & $\operatorname{tr}$ & T & MS \\
\hline Rapa & Ficus lancibracteata Corner & Moraceae & $\operatorname{tr}$ & B & $\mathrm{MR}, \mathrm{BS}$ \\
\hline Riqi & Pterocarpus indicus Willd. & Fabaceae & $\operatorname{tr}-\mathrm{m} / \mathrm{tr}-\mathrm{I}$ & $\mathrm{B}, \mathrm{T}$ & \\
\hline Ruqupole & Ocimum basilicum L. & Lamiaceae & hb/ssh & $(\mathrm{F}), \mathrm{T}$ & \\
\hline Saladia & Lactuca sativa $\mathrm{L}$. & Asteraceae & $\mathrm{hb}$ & $\mathrm{F}$ & \\
\hline Sasopo & Annona muricata L. & Annonaceae & $\operatorname{tr}-\mathrm{s}$ & $\mathrm{F}$ & \\
\hline Sili & Capsicum frutescens $\mathrm{L}$. & Solanaceae & $\mathrm{hb} / \mathrm{ssh}$ & $\mathrm{F}$ & \\
\hline Sosoruku & Sterculia shillinglawii Muell. & Sterculiaceae & $\operatorname{tr}$ & $\mathrm{T}$ & \\
\hline Suri & Diospyros sp., Timonius forsteri DC & & sh/tr-s & $B, T$ & $M P, M R, M L, B S$ \\
\hline Suti & Saccharum officinarium L. & Poaceae & $\mathrm{gr} / \mathrm{hb}$ & $\mathrm{F}$ & \\
\hline Talo & Colocasia esculenta (L.) Schott. & Araceae & $\mathrm{hb}$ & $\mathrm{F}$ & \\
\hline Tamata & Lycopersicon lycopersicum (L.) Karst. & Solanaceae & $\mathrm{hb}$ & $\mathrm{F}$ & \\
\hline Tatalise & Terminalia catappa L. & Combretaceae & tr-m & M & \\
\hline Tita & Parinari glaberrima (Hassk.) Hassk. & Chrysobalanaceae & $\operatorname{tr}$ & B & $M P, M R, M L$ \\
\hline Titimunuhaha & Clerodendrum buchananii (Roxb.) Walp. & Verbenaceae & sh/tr-s & M & \\
\hline Tivativa & Syzygium sp. & Myrtaceae & $\operatorname{tr}$ & T & MP \\
\hline Toqoneta & Timonius timon (Spreng.) Merr. & Rubiaceae & $\operatorname{tr}$ & $M, B, T$ & \\
\hline Tototu & Sonneratia caseolaris (L.) Engl. & Sonneratiaceae & $\operatorname{tr}$ & $B, T$ & MM \\
\hline
\end{tabular}


Table 1 List of plants used in the Roviana, sorted alphabetically by the Roviana name, with use purposes observed (Continued)

\begin{tabular}{|c|c|c|c|c|c|}
\hline Totuana & Alstonia spectabilis $\mathrm{R}$. Br. & Apocynaceae & $\operatorname{tr}$ & $M, B$ & MS, BP \\
\hline Tovinia & Canarium salomonense Burtt & Burseraceae & tr-m & $\mathrm{F}$ & \\
\hline Tukituki & Macaranga spp. & Euphorbiaceae & $\operatorname{tr}$ & $B, T$ & $M S, M L, B S$ \\
\hline Turutonoro & Horsfieldia irya (Gaertn.) Warb. & Myrtaceae & $\operatorname{tr}$ & B & $M R, M L, B S$ \\
\hline Uotakuresu & Nasturtium officinale R. Br. & Brassicaceae & hb & $\mathrm{F}$ & \\
\hline Valo & $\begin{array}{l}\text { Gonystylus macrophyllus (Miq.) A. } \\
\text { Shaw, G. megacarpus C.T. White }\end{array}$ & Thymelaeaceae & $\operatorname{tr}$ & B & $M P, M R, M S, M L$ \\
\hline Varu & Hibiscus tiliaceus L. & Malvaceae & $\operatorname{tr}$ & T & BS \\
\hline Vasara & Vitex cofassus Reinw. ex Bl. & Verbenaceae & tr-l & $B, T$ & $\mathrm{BP}, \mathrm{BS}$ \\
\hline Vasavasara & Geniostoma rupestris J.R. \& G. Forst. & Loganiaceae & $\operatorname{tr}$ & B & $M S, B P$ \\
\hline Vogi & Crinum asiaticum L. & Amaryllidaceae & hb & M & \\
\hline Voko & Ptychosperma salomonense Burret & Arecaceae & $\mathrm{pl}$ & T & \\
\hline Vorusu & Ceriops tagal (Pers.) C.B. Rob. & Rhizophoraceae & $\operatorname{tr}$ & B & \\
\hline Vosevose & Neonauclea spp. & Naucleaceae & $\operatorname{tr}$ & $B, T$ & $\mathrm{BP}, \mathrm{BS}$, \\
\hline Vuagore & Dysoxylum excelsum Bl. & Meliaceae & $\operatorname{tr}$ & T & BS \\
\hline Zamara & Commersonia bartramia (L.) Merr. & Sterculiaceae & tr-s & B & MS \\
\hline Zovi & Premna corymbosa (Burm. f.) R. \& W. & Verbenaceae & tr-s & $\mathrm{T}$ & \\
\hline $\begin{array}{l}\text { No name (introduced } \\
\text { plant) }\end{array}$ & Catharanthus roseus (L.) G. Don & Apocynaceae & hb & M & \\
\hline Name unidentified 1 & & & & B & \\
\hline Name unidentified 2 & & & & B & \\
\hline Name unidentified 3 & & & & B & \\
\hline Name unidentified 4 & & & & B & \\
\hline Name unidentified 5 & & & & B & \\
\hline Name unidentified 6 & & & & B & \\
\hline Name unidentified 7 & & & & $B$ & \\
\hline
\end{tabular}

a Plant type: $\mathrm{cl}=$ climber, $\mathrm{cr}=$ creeper, ep = epiphyte, $\mathrm{fn}=$ fern, $\mathrm{gr}=$ grass, $\mathrm{hb}=$ herb, sh = shrub, tr = tree (size unidentified), tr-s = tree-small $(<12 \mathrm{~m}$ tall), $\operatorname{tr}-\mathrm{m}=$ tree-medium (12-25 $\mathrm{m}$ tall), tr- $\mathrm{I}=$ tree-large ( $>25 \mathrm{~m}$ tall) (Henderson and Hancock [4]).

${ }^{b}$ Use purpose: $\mathrm{F}=$ food, $\mathrm{M}=$ medicine, $\mathrm{B}=$ building, $\mathrm{T}=$ tool; use purposes observed during the research periods are shown; those observed outside of the study period were also shown in parenthesis.

${ }^{c}$ Forest class: $\mathrm{MP}=$ main island, primary forest, $\mathrm{MR}=$ main island, reserve forest, $\mathrm{MS}=$ main island, secondary forest, $\mathrm{ML}=\mathrm{main}$ island, logged forest, $\mathrm{BP}=$ barrier island, primary forest, $\mathrm{BS}$ = barrier island, secondary forest, $\mathrm{MM}$ = main island, mangrove; only trees observed in this study were shown.

tree or palm species used most frequently for tools. Vitex ( $V$. cofassus) was used in all households in both villages to make paddles, wood mortar, agricultural tools, and furniture. Kapok and B. malabaricum fiber were used for pillows in almost all households $(86.7 \%$ and $100 \%$ in the rural and urban villages, respectively). Coconut palm leaves were used for hats, bags, fans, and other items, while sago palm leaves were used for brooms. White beech was one of the most important tree species because canoes are made exclusively from this species (80.0\% and $70.6 \%$ in the rural and urban households, respectively). A significant difference between the two villages $(66.7 \%$ in the rural village, $0 \%$ in the urban one) was found in the use of large-leafed mangroves, because mangrove forests are abundant only in the rural village. The mangroves were used as sticks or knives to open coconut fruit (viviguana in the Roviana language). A difference was also observed (93.3\% and $23.5 \%$ in the rural and urban villages, respectively) in the use of premna (Premna corymbosa Rottler \& Willd.) for amulets, including amulets used to fish or ward off devil spirits, for example. This customary charm was less frequently found in the urban village.

\section{Distribution of useful trees in different forest types and islands}

In the vegetation quadrat surveys conducted on the main island, 168 (31 species), 120 (49), 181 (48), and 180 (49) individual trees $(>10 \mathrm{~cm} \mathrm{DBH})$ were found in the four quadrats in the primary, reserve, secondary, and logged forests, respectively (Table 6). In addition, 137 trees (10 species) were observed in the mangrove habitat. On the barrier island, 117 (19 species) and 124 (36) trees were found in the primary and secondary forests, respectively. 
Table 2 Six tree-like or palm food species that contributed the most to villagers' energy intakes

\begin{tabular}{|c|c|c|c|c|}
\hline \multirow[t]{2}{*}{ Common name } & \multirow[t]{2}{*}{ Scientific name } & \multirow[t]{2}{*}{ Roviana name } & \multicolumn{2}{|c|}{$\%$ total energy intake } \\
\hline & & & Urban & Rural \\
\hline Coconut & Cocos nucifera $\mathrm{L}$. & Nohara & 3.9 & 4.3 \\
\hline Canarium nut & Canarium indicum L./C. salomonense Burtt & Okete/tovinia & 0.1 & 3.9 \\
\hline Banana & Musa spp. & Hakua & 2.2 & 0.4 \\
\hline Papaya & Carica papaya L. & Manioko & 0.6 & 0.1 \\
\hline Large-leafed mangrove & Bruguiera gymnorhiza (L.) Lam. & Petu & 0 & 0.04 \\
\hline Gnetum & Gnetum gnemon L. & Lege & 0.02 & 0 \\
\hline
\end{tabular}

The number of trees observed in the plant use survey quadrats was 87 (15 species), 82 (26), 53 (18), 80 (12), and 77 (16) in the main island's primary, reserve, and secondary forests and the barrier island's primary and secondary forests, respectively. A total of 87 trees (6 species) were found in the mangrove quadrats (Table 6). The proportion of useful trees was high in the barrier island's primary forest $(68.4 \%)$ and the main island's reserve $(68.3 \%)$ and low in the main island's secondary forest (29.3\%). Figure 3 shows the numbers of trees of representative useful species found in the respective forest use classes. Calophyllum (Calophyllum spp.), a primary building material, was predominantly found on the main island and in primary and reserve forests. Dillenia (D. salomonensis) was found only in the reserve forests. Commersonia (C. bartramia), an important building material in the rural village, and white beech, a rare species, were found only in the secondary forests. Vitex ( $V$. cofassus), an important building and tool species, was found on both islands, although it was more frequently observed on the barrier islands. These results suggest that each forest class has a different level of importance to the peoples' subsistence lifestyle.

Table 7 shows the similarities between the different types of vegetation. The primary forests on the main and barrier islands were only half as similar (16.0\%) as the respective secondary forests $(33.3 \%)$. Vegetation in the reserve forests was $45.9-52.6 \%$ similar to that found in the primary, secondary, and logged forests on the main island but less similar to the primary and secondary forests on the barrier island (17.4-33.8\%). Species found in the mangrove forest were not observed in other forest classes. These results suggest that each forest class represented a different vegetative community, with relatively low rates of similarity between communities. Assuming that primary forest represented areas with little human impacts, several unique species were found in human-modified forests (i.e., reserve forest and secondary forests). The vegetation on the main and barrier islands was very different.

Figure 4 shows the proportions of plants used for building materials and tools in the different forest classes by the urban and rural people. Primary forest trees used as building materials accounted for $36.0 \%$ of the urban village tree species and only $26.6 \%$ of the rural village tree species $\left(\chi^{2}=7.7, P=0.004\right)$; however, most of the building materials in the former group were timbers purchased from logging companies operating in neighboring areas. In the reserve forests, $52.3 \%$ of the trees were species used by the rural people as building materials; this proportion was only $18.4 \%$ in the urban village $\left(\chi^{2}=58.6, P<0.001\right)$. Trees found in

Table 3 Nine tree or palm species used in two or more person-days to treat illness

\begin{tabular}{|c|c|c|c|c|c|c|}
\hline \multirow{3}{*}{$\begin{array}{l}\text { Common name } \\
\text { Coconut }\end{array}$} & \multirow{3}{*}{$\begin{array}{l}\text { Scientific name } \\
\text { Cocos nucifera L. }\end{array}$} & \multirow{3}{*}{$\begin{array}{l}\text { Roviana name } \\
\text { Nohara }\end{array}$} & \multicolumn{4}{|c|}{ Frequency of use: no. of person-days (\%) } \\
\hline & & & \multicolumn{2}{|c|}{ Urban } & \multicolumn{2}{|c|}{ Rural } \\
\hline & & & 25 & $(15.7)$ & 5 & $(2.0)$ \\
\hline Ylang-ylang & Cananga odorata (Lamk.) Hook. f. \& Thoms. & Nagarita & 25 & $(15.7)$ & 0 & $(0)$ \\
\hline Tropical almond & Terminalia catappa L. & Tatalise & 0 & $(0)$ & 5 & $(2.0)$ \\
\hline Betel nut & Areca catechu L. & Heta & 0 & $(0)$ & 4 & $(2.0)$ \\
\hline Great morinda & Morinda citrifolia L. & Gurata & 4 & $(2.5)$ & 0 & (0) \\
\hline Timonius timon & Timonius timon (Spreng.) Merr. & Toqoneta & 0 & $(0)$ & 2 & $(1.0)$ \\
\hline Red clerodendrum & Clerodendrum buchananii (Roxb.) Walp. & Titimunuhaha & 0 & $(0)$ & 2 & $(1.0)$ \\
\hline Native mulberry & Pipturus argenteus (Forst. f.) Wedd. & Nekete & 0 & $(0)$ & 2 & $(1.0)$ \\
\hline Key lime & Citrus aurantifolia (Christm.) Swing. & Laini & 1 & $(0.6)$ & 1 & $(0.5)$ \\
\hline
\end{tabular}


Table 4 Eleven tree or palm species used in the highest frequencies for building houses

\begin{tabular}{|c|c|c|c|c|c|}
\hline \multirow[t]{2}{*}{ Common name } & \multirow[t]{2}{*}{ Scientific name } & \multirow[t]{2}{*}{ Roviana name } & \multicolumn{2}{|c|}{ Frequency of use: $\%$ household using } & \multirow[t]{2}{*}{ Main purposes } \\
\hline & & & Urban & Rural & \\
\hline Calophyllum & Calophyllum spp. & Buni & 100 & 100 & Floor, Wall, Post \\
\hline Vitex & Vitex cofassus Reinw. ex Bl. & Vasara & 88.2 & 100 & Floor, Wall, Post \\
\hline Sago palm & Metroxylon spp. & Edeve & 82.4 & 93.3 & Roof, Wall \\
\hline Rattan & Calamus spp. & Aroso & 82.4 & 93.3 & Rope \\
\hline Betel nut palm (wild) & Areca macrocalyx Zipp. Ex BI. & Heta pinomo & 82.4 & 93.3 & Rafter, Wall, Floo \\
\hline Flueggea & Flueggea flexuosa Müll.Arg. & Mavuana & 70.6 & 93.3 & Post \\
\hline Fijian longan, taun & Pometia pinnata Forst. f. & Qema & 94.1 & 20.0 & Floor, Wall, Post \\
\hline Large-leafed mangrove & Bruguiera gymnorhiza (L.) Lam. & Petu & 47.1 & 66.7 & Post, Rafter \\
\hline Brown Kurrajong & Commersonia bartramia (L.) Merr. & Zamara & 0 & 66.7 & Rafter, Beam \\
\hline Timonius timon & Timonius timon (Spreng.) Merr. & Toqoneta & 41.2 & 13.3 & Beam \\
\hline Dillenia salomonensis & Dillenia salomonensis (C.T. White) Hoogl. & Kapuhu & 0 & 46.7 & Floor, Post \\
\hline
\end{tabular}

the mangrove forests were seldom used to make tools in the urban village, where few mangroves remained, while $62.3 \%$ of the tree species in the mangroves were used in the rural village. The reserve forests had more useful tree species in the rural $(16.7 \%)$ village than in the urban village $\left(6.7 \% ; \chi^{2}=10.7, P=0.001\right)$. These results suggest that the reserve and mangrove forests, which existed exclusively in the rural village, provided the rural people with a number of useful resources that the urban people did not have access to.

In the urban village, materials that were not available from forests were purchased. For instance, large-leafed mangrove sticks were used to pry open coconuts (viguvigua in Roviana) in nine of 15 households in the rural village, while imported iron was used for this purpose in the urban village.

\section{Discussion and conclusions}

Subsistence use depends on the botanical diversity in human-modified forests

This study documented how the Roviana people traditionally use each of several forest types and how each forest type supports different plant species that are used for various purposes. We examined four use categories of plants: food, medicine, building materials, and tools (Tables 2, 3, 4 and 5, respectively). Coconut was represented in all four use categories, suggesting that this plant is the most important species for the Roviana people. Coconut is important in Pacific Island societies because it provides a high-calorie source of food, building materials, herbal medicines, and fuel $[4,5,43]$. A mangrove species (B. gymnorrhiza) was used in three (foods, building, and tools) of the four use categories.

Table $\mathbf{5}$ Thirteen tree or palm species used in the highest frequencies for tools

\begin{tabular}{|c|c|c|c|c|c|}
\hline \multirow[t]{2}{*}{ Common name } & \multirow[t]{2}{*}{ Scientific name } & \multirow[t]{2}{*}{ Roviana name } & \multicolumn{2}{|c|}{$\begin{array}{l}\text { Frequency of use: } \\
\% \text { household using }\end{array}$} & \multirow[t]{2}{*}{ Main purpose } \\
\hline & & & Urban & Rural & \\
\hline Vitex & Vitex cofassus Reinw. ex Bl. & Vasara & 100 & 100 & Paddle, Furniture, Mortar, Plow \\
\hline Kapok & Ceiba pentandra (L.) Gaertn., Bombax malabaricum DC. & Lozi & 100 & 86.7 & Pillow \\
\hline Coconut palm & Cocos nucifera L. & Nohara & 100 & 86.7 & Basket, Hat \\
\hline Sago palm & Metroxylon spp. & Edeve & 82.4 & 93.3 & Broom \\
\hline Rattan & Calamus spp. & Aroso & 88.2 & 86.7 & Chair, Tong \\
\hline Calophyllum & Calophyllum spp. & Buni & 76.5 & 93.3 & Spear hand, Furniture \\
\hline Fijian longan, taun & Pometia pinnata Forst. f. & Qema & 82.4 & 80.0 & Axe hand \\
\hline Pemphis & Pemphis acidula J.R. \& G. Forst. & Bobogele & 94.1 & 60.0 & Pestle, Coconut opener \\
\hline White beech & Gmelina moluccana Backer ex K.Heyne & Qoliti & 70.6 & 80.0 & Canoe \\
\hline Pandanus & Pandanus sp. & Dalou & 41.2 & 80.0 & Mat \\
\hline Premna & Premna corymbosa Rottler \& Willd. & Zovi & 23.5 & 93.3 & Amulet \\
\hline Pandanus tectorius & Pandanus tectorius Park. & Pate & 29.4 & 40.0 & Mate \\
\hline Large-leafed mangrove & Bruguiera gymnorhiza (L.) Lam. & Petu & 0 & 66.7 & Pestle, Coconut opener \\
\hline
\end{tabular}


Table 6 The numbers of trees, tree species, and proportions of useful trees found in each forest class

\begin{tabular}{|c|c|c|c|c|c|c|}
\hline & $\begin{array}{l}\text { No. of trees } \\
\text { (per } 1 / 4 \mathrm{ha} \text { ) }\end{array}$ & $\begin{array}{l}\text { No. of species } \\
\text { (per } 1 / 4 \mathrm{ha} \text { ) }\end{array}$ & $\begin{array}{l}\text { No. of useful trees } \\
\text { (per } 1 / 4 \mathrm{ha} \text { ) }\end{array}$ & $\begin{array}{l}\text { No. of useful species } \\
\text { (per } 1 / 4 \mathrm{ha} \text { ) }\end{array}$ & $\%$ of useful trees & $\%$ of useful species \\
\hline \multicolumn{7}{|l|}{ Main island (Tutupeka) } \\
\hline Primary & 168 & 31 & 87 & 15 & 51.8 & 48.4 \\
\hline Reserve $^{a}$ & $120(122,117)$ & $49(27,41)$ & 82 & 26 & 68.3 & 53.1 \\
\hline Secondary & 181 & 48 & 53 & 18 & 29.3 & 37.5 \\
\hline Mangrove & 137 & 10 & 87 & 6 & 63.5 & 60.0 \\
\hline Logged (selectively) & 180 & 49 & 92 & 20 & 51.1 & 40.8 \\
\hline \multicolumn{7}{|l|}{ Barrier island (Toba) } \\
\hline Primary & 117 & 19 & 80 & 12 & 68.4 & 63.2 \\
\hline Secondary & 124 & 36 & 77 & 16 & 62.1 & 44.4 \\
\hline
\end{tabular}

${ }^{a}$ Two quadrats (1/4 ha each) were made and the number of trees were averaged for the reserve (the numbers of trees and species for respective quadrats were shown in the parentheses).

According to a previous study, mangroves also have various purposes (i.e., food, medicine, building materials, tools, firewood) in Marovo [5], and mangroves are believed to have traditionally played important roles in the subsistence of the Western Solomon Islanders. Timonius timon (Spreng.) Merr., which is not commonly used in other societies, was also used in three categories, i.e., medicine, building materials, and tools. This tree grows wild on cleared land and roadsides. The people weed its seedlings in their gardens or plantation areas but leave it untouched elsewhere; in addition, they sometimes cut/ weed trees that might harm nearby timonius trees to help timonius tree growth. Such behaviors, called "semidomestication" $[47,48]$, were observed with other plants, such as gnetum and premna. The villagers thus enjoyed a range of ecological services provided by the biodiversity that was preserved in their forests.

\section{Traditional ways of subsistence may contribute to forest biodiversity}

The biodiversity of the landscape was related to the people's use and management of forest resources. We found that the human-modified reserve and secondary forests represented distinct vegetative communities that are very different from both the primary forest, which has experienced few human impacts, and from one another (Tables 6 and 7, Figure 3). For example, some pioneer species (e.g., D. salomonense) grew only in forest gaps in the reserve forest and not in mature forest; these gaps were created by the regular cutting of useful trees by the villagers (which was permitted, although commercial use or clearance for gardens was not) for their subsistence. Others (e.g., C. bartramia and G. mollucana) occurred only in secondary forest (Figure 3, Table 7), which regrew after shifting cultivation crop fields were abandoned when productivity decreased. In addition, semidomestication is also thought to have promoted the growth of specific species, such as timonius, which are uncommon in the wild but sometimes encouraged by the villagers when they do occur $[47,48]$. Thus, regular subsistence use of the forests by humans may have resulted in multiple unique vegetative communities, and higher overall biodiversity, than would otherwise exist. Alternatively, the diverse vegetative communities may have attracted the people, but this

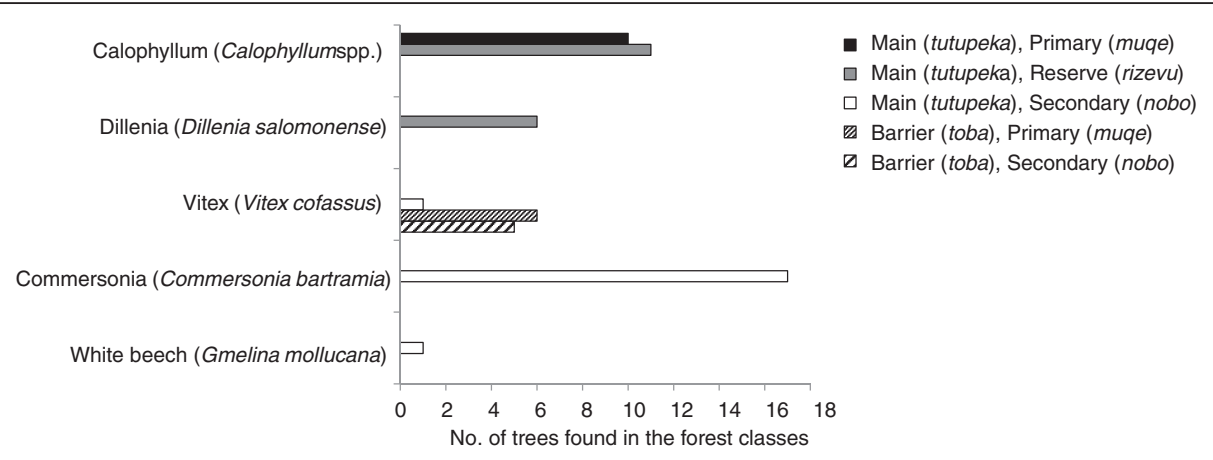

Figure 3 Number of selected useful trees in each forest class. 
Table 7 Sørensen similarity index (\%) between different forest classes

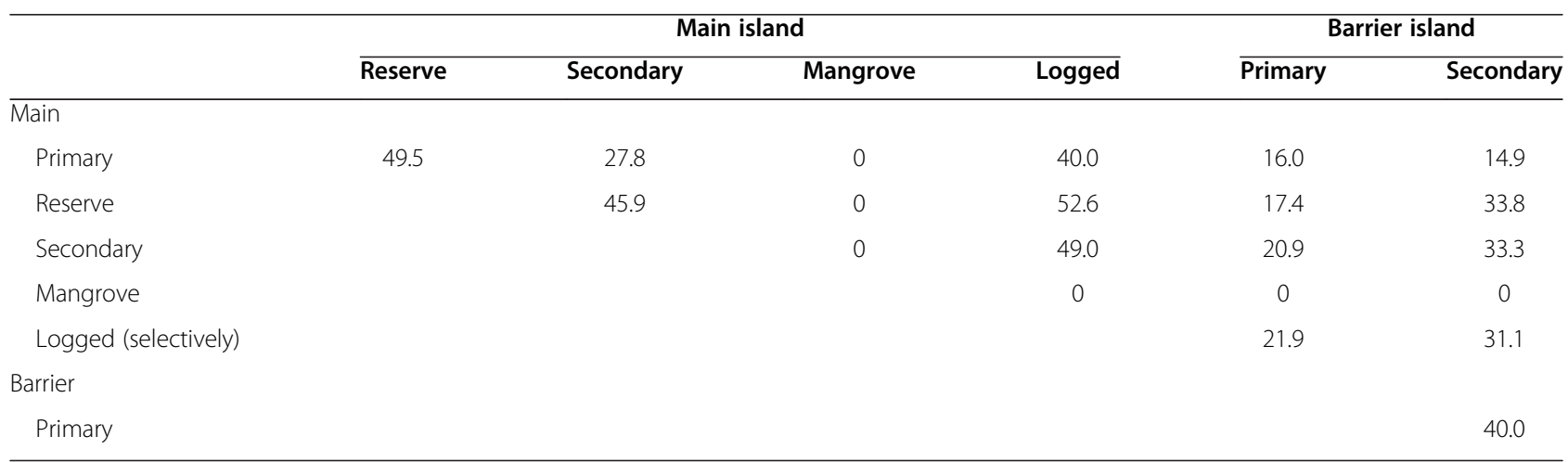

hypothesis is contradicted by the small number of forest types near the more populous urban village. The logical conclusion is that the existence of a variety of forest classes, i.e., human-modified forests, both increases diversity and provides an essential base for the rural people's subsistence.

\section{Socioeconomic changes can affect diversity, even in ecologically-autonomous communities}

In Dunde village, biodiversity has already been lost. The reserve and mangrove forests no longer exist or are severely diminished. Consequently, the urban people did not enjoy the ecological services of useful plants that would be expected in those habitats. For example, the mangrove has been an important useful plant in this area (see above), but it was rare in the urban areas, and its rate of use was low. The Dunde villagers were required to purchase other tree resources using cash or use modern materials to compensate for this lost biodiversity.

In recent years, under an expanded market economy, widespread commercial logging has been carried out, and industrial reforestation is now being implemented in logged areas. This trend, if it continues, could destroy the residents' source of livelihood, triggering a decrease in the number and variety of forest species. Although industrial timber plantations will contribute to increased biomass, they may interrupt the original cycle of biodiversity and disrupt the relationships between humans and forests. People will lose access to vital ecosystem

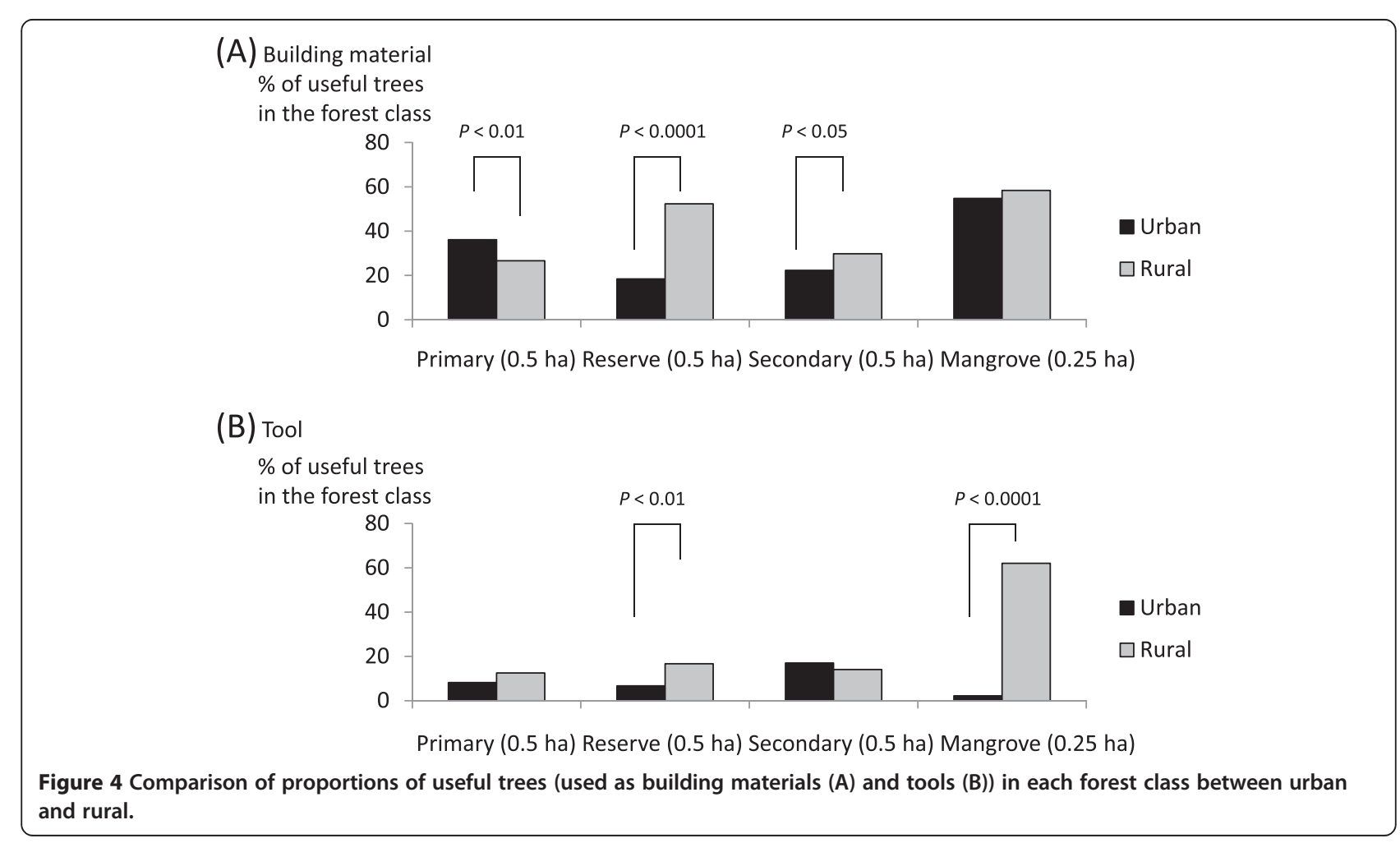


services from their range of forest classes if logging and cash crop planting continues unabated $[23,49]$. Building timber plantations will not replace the current ecosystem benefits. Previous studies have suggested that shifts from subsistence agriculture to cash crops have adversely affected labor, the economic status, and natural productivity in other parts of Solomon Islands $[5,19,40,49,50]$. In contrast, a recent monetary study reported that villagers were willing to pay a high proportion of their incomes to conserve ecosystem services [51]. Thus, efforts to conserve forest biodiversity may also economically benefit the Roviana people.

\section{Biodiversity conservation programs can integrate local peoples' modifications of forests Local people possess vital conservation knowledge}

Throughout this study, the rural people conserved various forest types and thus preserved the diversity of tree species while enjoying the benefits of the forests in their territories. There are customary rules about forest conservation in Olive, such as for the use of a canoe-making tree, the white beech. When a person needs a new canoe, he/she must find a young white beech tree and mark it to inform the other residents of its intended use. Then, when the time comes to make the canoe, he/she must ask for the customary chief's permission. This tree is also grown on cleared land [3,39]; therefore, human modification contributes to the sustainability of this resource. There is also a rule for gathering sago palm (Metroxylon spp.) leaves, an essential roof and wall material in traditional houses: because a sago palm takes a very long time to regrow once the trunk is cut, the trunk must be left untouched and only the leaves can be removed. Four leaves should also remain on the tree, because it will die if all the leaves are removed (Figure 5). If a villager violates this rule, he/she will be penalized by the chief (e.g., compensation payment). According to the interviewees, the rural people established the reserve forest in the 1970-80s based on the recommendation of the leader of the CFC and the chief; this was because they intended to expand a coconut plantation for cash income and the logging operation had been coming near their territory. These cases suggest that local leadership, especially from the chief and church leaders, and traditional ecological knowledge are important for conservation.

\section{Traditional forest uses can enhance biodiversity conservation and quality of life}

Local leaders play important roles in the conservation of biodiversity. However, a dilemma now exists because these leaders are also leading rural development initiatives aimed at improving the quality of people's lives [46]. The same situation exists at the national level. Generally, the governments of the Pacific Island countries

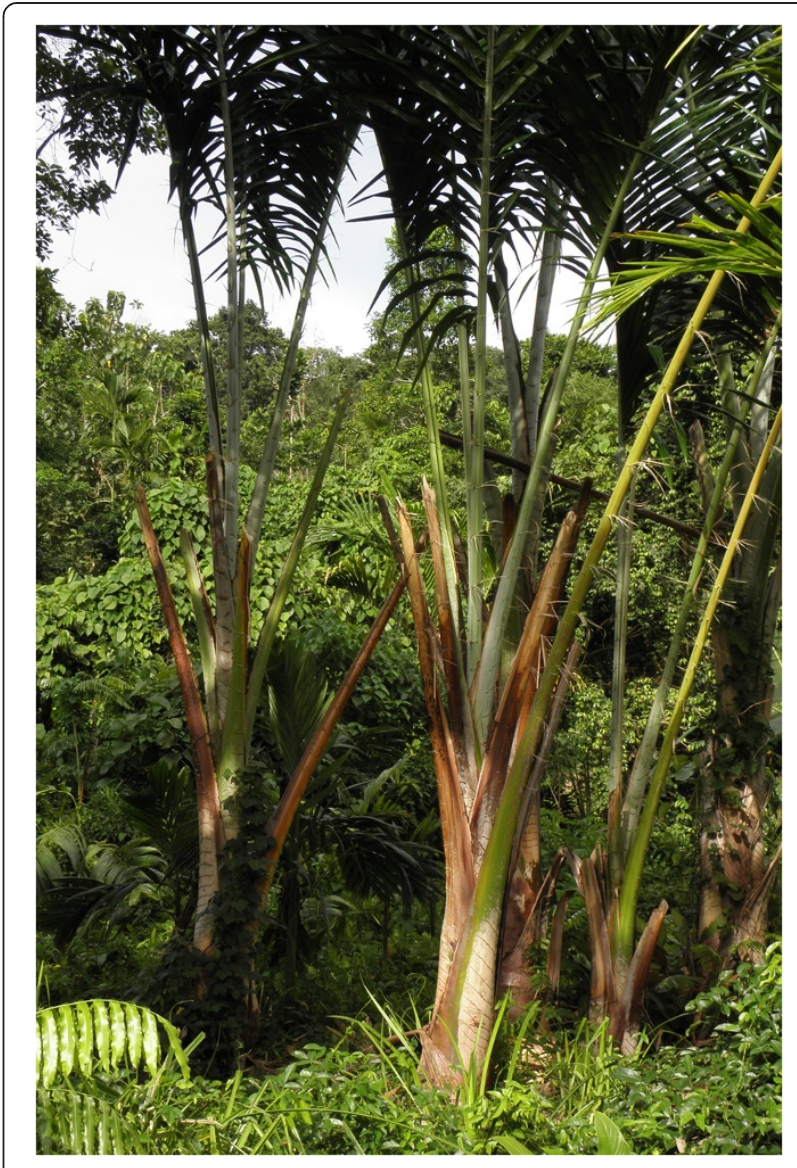

Figure 5 Sago palm with four leaves remaining after the villagers collected the other leaves.

depend on the production of natural resources for revenue. In addition, even if a government tries to take action related to natural resource conservation, successful outcomes are difficult to achieve because most territories consist of lands with customary uses designated by the local people; a group of land owners may not agree on conservation but might accept development projects [6]. From the viewpoint of biodiversity conservation, the rural residents of Solomon Islands, whose livelihoods depend heavily on farming and fishing, have no choice but to continue making a living using natural resources. Even for the sake of conserving natural resources, it is virtually impossible to persuade people to leave unmodified forests untouched. Even if such ideas were accepted, the agreements are unlikely to become permanent.

Recent studies have suggested that, worldwide, there exist few pristine natural areas that are free from any human impacts [52]. Top-down efforts to conserve pristine environments, with a few exceptions, have failed, so that recent conservation focus has shifted to new paradigm of incorporating a productive landscape, social institutions, and human-modified forests [12,13,53]. 
Conservation activities are also more efficient if conservation forests and production lands are separated, but tropical societies [54], as in this study, depend strongly on their forests for production. Conservation efforts, either community-based or by outsider's initiatives, have to allow for human uses of forests rather than trying to protect pristine environments, such as in the zone-based conservation model [55]. The findings of this study suggest that conservation of virgin forest is not acceptable to the Roviana people, who live in human-modified forests, and may diminish biodiversity. Therefore, the focus of conservation must shift toward human-modified forests where the people use the natural resources in a sustainable way, as in the Satoyama Initiative in the CBD [16-18]. However, this human-environment relationship is easily transformed during socioeconomic changes.

\section{Conclusions}

We identified four major limitations of our study. First, we only interviewed four landscape experts (although this number compared favorably with previous studies [10]). Knowledge regarding the forest varied within the community; e.g., the younger generations were less informed. Therefore, we used only forest experts that were recommended by village leaders and who were respected in the villages for their traditional ecological knowledge. These experts rarely disagreed with one another on forest knowledge. Indigenous people of Solomon Islands and other Melanesian societies know their vegetative communities $[5,11]$. We thus believe that our informants were representative of the villagers' knowledge of landscape classification.

A second limitation was logistic; we could not feasibly survey all recognized vegetation classifications. We choose 15-year-old fallow areas to represent secondary forests because forests of this age existed on both the main and barrier islands, and the villagers could accurately identify the age by referring to important events. Other forest types, such as hope and emata, were small or difficult to distinguish from other forest classes (i.e., 'primary' or 'secondary' forests). While this study may not have revealed all of the vegetative differences at the study sites, our data well represented the diversity of forest uses and revealed clear differences between the urban and rural villages.

Third, to protect the villagers' intellectual property and privacy, we did not record some kinds of plant uses, such as magical purposes and medicines. Fourth, our observations were restricted to a season and may not represent all forest uses throughout the year. However, compared with our previous work in these villages and with others studies of neighboring areas $[4,5]$, our results included most human physical effects on forest trees.

The findings of this study from the urban village suggested that the Roviana people can also maintain their lifestyle without the ecological services provided by biodiversity, although much effort is required to earn cash as alternatives to reserves and mangroves. However, this model is not sustainable, because, as observed in our previous study, approximately one-third of the urban villagers earn the same amount of cash as the rural villagers [33]. In addition, the purchased materials are produced from logging operations in rural forests $[15,18]$. Therefore, it may be necessary to provide economic incentives to conserve human-modified forests, i.e., conserving biodiversity while using ecological services. In addition, a loss of economic use, e.g., the fact that mangroves are now a low-priority resource and at risk of disappearing in urban areas, may lead to loss of traditional knowledge and cultural diversity. Our results highlight the importance of human-modified forests in forest conservation initiatives, such as REDD + (reducing emissions from deforestation and forest degradation in developing countries and the role of conservation, sustainable management of forests and the enhancement of forest carbon stocks in developing countries) or PES (payment for ecosystem services).

\section{Competing interests}

The authors declare that they have no competing interests.

\section{Authors' contributions}

TF designed the study. TF, MS, and RO carried out the field research. MQS identified the scientific names of the plant specimens. RO supervised the work. TF performed the statistical analyses. TF, MQS, and MS analyzed the data and wrote the manuscript. All authors read and approved the final version of the manuscript.

\section{Acknowledgements}

We sincerely thank the people of Roviana and the staff at the Ministry of Forestry, Environment and Conservation and Ministry of Health and Medical Services, Solomon Islands. We are also grateful to anonymous referees for their valuable comments and suggestions on this paper. A part of this study was commissioned by the Ministry of the Environment, Japan. A summary of this report has been published in the CBD Technical Series No. 52 by the Secretariat of the Conservation of Biological Diversity [56]. Other parts of this study were based on research projects funded by a Japan Society for the Promotion of Science (JSPS) Research for the Future Program and a KAKENHI grant-in-aid.

\section{Author details}

${ }^{1}$ Graduate School of Asian and African Area Studies, Kyoto University, Room \#AA431, Research Bldg. No. 2, Yoshida-Honmachi, Sakyo-ku, Kyoto 606-8501, Japan. ${ }^{2}$ National Herbarium \& Botanical Gardens, Ministry of Forestry, Honiara, Solomon Islands. ${ }^{3}$ Graduate School of Letters, Hokkaido University, Kita 10, Nishi 7, Kita-ku, Sapporo 060-0810, Japan. ${ }^{4} J a p a n$ Wildlife Research Center (JWRC), 3-3-7 Kotobashi, Sumida-ku, Tokyo, Japan.

Received: 10 January 2013 Accepted: 7 January 2014 Published: 27 January 2014

\section{References}

1. Conservation International: Overview: East Melanesian Islands: The Hotspots Asia-Pacific. http://www.conservation.org/where/priority_areas/hotspots/asiapacific/East-Melanesian-Islands/Pages/default.aspx.

2. Brooks TM, Mittermeier RA, da Fonseca GAB, Gerlach J, Hoffmann M, Lamoreux J, Mittermeier CG, Pilgrim JD, Rodrigues ASL: Global biodiversity conservation priorities. Science 2006, 313:58-61 
3. Bayliss-Smith T, Hviding E, Whitmore T: Rainforest composition and histories of human disturbance in Solomon Islands. AMBIO 2003, 32:346-352

4. Henderson CP, Hancock IR: A Guide to the Useful Plants of Solomon Islands. Ministry of Agriculture and Lands: Honiara; 1988.

5. Hviding E, Bayliss-Smith T: Islands of Rainforest: Agroforestry, Logging and Eco-tourism in Solomon Islands. Aldershot: Ashgate; 2000.

6. Centre pour I' Environnement et le Developpement (CED) and Association Okani (Cameroon), South Central Peoples Development Association (SCPDA) (Guyana), Organisation of Kaliña and Lokono in Marowijne (KLIM) (Suriname), Inter-Mountain People Education \& Cultures in Thailand Association (IMPECT) (Thailand), Forest Peoples Programme (United Kingdom): Customary sustainable use of biodiversity by indigenous peoples: case studies relevant to the Satoyama Initiative from Suriname, Guyana, Cameroon and Thailand. In Sustainable Use of Biological Diversity in Socio-ecological Production Landscapes; CBD Technical Series no. 52. Edited by Bélair C, Ichikawa K, Wong B, Mulongoy K. Montreal: Secretariat of the Convention on Biological Diversity; 2010:22-35.

7. Hviding E: Kiladi Oro Vivineidi Ria Tingtonga pa Idere Oro pa Goana pa Marovo /Reef and Rainforest: An Environmental Encyclopedia of Marovo Lagoon, Solomon Islands. Paris: UNESCO; 2005.

8. Pikacha PG: Wild West: Rainforests of Western Solomon Islands. Honiara: Melanesian Geo Publication; 2008.

9. Kwaioloa M, Burt B: Our Forest Kwara'ae: Our Life in Solomon Islands and Things Growing in Our Home/Na Masu's Kia 'i Kwara'aw: Tualaka 'I Solomon Islands Fa'inia Logo na ru Bulao ki Saena Fanoa Kia. London: British Museum Press; 2001.

10. Ellen R: Local and scientific understanding of forest diversity on Seram, Eastern Indonesia. In Local Science vs Global Science: Approaches to Indigenous Knowledge in International Development. Edited by Sillitoe P. New York: Berghahn Books; 2007:41-74.

11. Sillitoe P: An ethnobotanical account of the vegetation communities of the Wola region, Southern Highlands Province, Papua New Guinea. Journal of Ethnobiology 1998, 18:103-128.

12. Myers N, Mittermeier RA, Mittermeier CG, Da Fonseca GAB, Kent J: Biodiversity hotspots for conservation priorities. Nature 2000, 403:853-858

13. Adams WM, Aveling R, Brockington D, Dickson B, Elliott J, Hutton J, Roe D, Vira B, Wolmer W: Biodiversity conservation and the eradication of poverty. Science 2004, 306:1146-1149.

14. van Oudenhoven FJW, Mijatović D, Eyzaguirre PB: Bridging managed and natural landscapes: the role of traditional (agri)culture in maintaining the diversity and resilience of social-ecological systems. In Sustainable Use of Biological Diversity in Socio-ecological Production Landscapes, CBD Technical Series no. 52. Edited by Bélair C, Ichikawa K, Wong B, Mulongoy K. Montreal: Secretariat of the Convention on Biological Diversity; 2010:8-21.

15. Sanderson S, Redford K: The defence of conservation is not an attack on the poor. Oryx 2004, 38:146-147.

16. Takeuchi $\mathrm{K}$ : Rebuilding the relationship between people and nature: the Satoyama Initiative. Ecol Res 2010, 25:891-897.

17. Bélair C, Ichikawa K, Wong B: Mulongoy K (Eds): Sustainable Use of Biological Diversity in Socio-ecological Production Landscapes CBD Technical Series no. 52. Secretariat of the Convention on Biological Diversity: Montreal; 2010.

18. SATOYAMA Initiative. http://satoyama-initiative.org/.

19. Bennett JA: Pacific Forest: A History of Resource Control and Contest in Solomon Islands, c.1800-1997. Cambridge: White Horse Publisher; 2000.

20. Aswani S, Albert S, Sabetian S, Furusawa T: Customary management as precautionary and adaptive principles for protecting coral reefs in Oceania. Coral Reefs 2007, 26:1009-1021.

21. Carter B: Conservation Strategy for the Island of Tetepare. WWF Pacific: Gizo; 1997.

22. Read J, Moseby K: Vertebrates of Tetepare Island, Solomon Islands. Pac Sci 2006, 60:69-79.

23. Fazey I, Pettorelli N, Kenter J, Wagatora D, Schuett D: Maladaptive trajectories of change in Makira, Solomon Islands. Global Environ Change 2011, 21:1275-1289.

24. Bennett JA: Wealth of the Solomons: A History of a Pacific Archipelago, 1800-1978. Honolulu: University of Hawaii Press; 1987.

25. Furusawa T, Ohtsuka R: The role of barrier islands in subsistence of the inhabitants of Roviana Lagoon, Solomon Islands. Hum Ecol 2009, 37:629-642.

26. Solomon Islands Government: Medium Term Development Strategy 1999-2001, Volume 1: Policy and Strategy. Honiara: Solomon Islands Government; 1999.
27. Schneider G: Reinventing identities: redefining cultural concepts in the struggle between villagers in Munda, Roviana Lagoon, New Georgia Island, Solomon Islands, for the control of land. In Pacific Answers to Western Hegemony: Cultural Practices of Identity Construction. Edited by Wassmann J. Oxford: Berg; 1998:191-221.

28. Prance GT, Baleé W, Boom B, Carneiro R: Quantitative ethnobotany and the case for conservation in Amazonia. Conserv Biol 1987, 1:296-310.

29. Phillips O, Gentry A, Reynel C, Wilkin P, Galvez-Durand C: Quantitative ethnobotany and Amazonian conservation. Conserv Biol 1994, 8:225-248.

30. Solomon Islands National Statistics Office: Report on 2009 Population and Housing Census: Basic Tables and Census Description. Honiara: Statistics Office; 2011.

31. Lewis MP: Summer Institute of Linguistics: Ethnologue: Languages of the world, Volume 9. Dallas: SIL International; 2009.

32. Furusawa T: Changing ethnobotanical knowledge of the Roviana people, Solomon Islands: quantitative approaches to its correlation with modernization. Hum Ecol 2009, 37:147-159.

33. Furusawa T: Ecological and economic analyses of urbanization in the customary lands of the Solomon Islands. People and Culture in Oceania 2011, 27:1-17.

34. Aswani S: Common property models of sea tenure: a case study from the Roviana and Vonavona Lagoons, New Georgia, Solomon Islands. Hum Ecol 1999, 27:417-453.

35. Aswani S: Changing identities: the ethnohistory of Roviana predatory head-hunting. J Polynesian Soc 2000, 109:39-70.

36. Nagaoka T: Hope Pukerane: A Study of Religious Sites in Roviana, New Georgia, Solomon Islands, MA thesis. Auckland: University of Auckland; 1999.

37. Furusawa T, Pahari K, Umezaki M, Ohtsuka R: Impacts of selective logging on New Georgia Island, Solomon Islands evaluated using very-highresolution satellite (IKONOS) data. Environ Conserv 2004, 31:349-355.

38. Furusawa T: The roles of Western biomedicine and folk medicine in rural Solomon Islands: a quantitative analysis. Trop Med Health 2006, 34:83-91.

39. Whitmore TC: Guide to the Forest of the British Solomon Islands. London: Oxford University Press; 1966.

40. Hviding E: Guardians of Marovo Lagoon: Practice, Place, and Politics in Maritime Melanesia. Honolulu: University of Hawaii Press; 1996.

41. Aswani S, Vaccaro I: Lagoon ecology and social strategies: habitat diversity and ethnobiology. Hum Ecol 2008, 36:325-341.

42. Bernstein J, Ellen RF, Antaran B: The use of plot surveys for the study of ethnobotanical knowledge: a Brunei Dusun example. Journal of Ethnobiology 1997, 17:69-96.

43. Dignan CA, Burlingame BA, Arthur JM, Quigley RJ, Milligan GC: The Pacific Islands Food Consumption Tables. Palmerston North: New Zealand Institute for Crop and Food Research; 1994.

44. Puwastien P, Burlingame B, Raroengwichit M, Sungpung P: ASEAN Food Composition Tables. Nakorm Pathom: Institute of Nutrition, Mahidol University; 2000

45. Looman J, Campbell JB: Adaptation of Sorensen's K (1948) for estimating unit affinities in prairie vegetation. Ecology 1960, 41:409-416.

46. Racelis AE, Aswani S: Hopes and disenchantments of religious community forestry in the Western Solomon Islands. Ecological and Environmental Anthropology 2011, 6:26-38.

47. Matsui T: Semidomestication: Rethinking the Origins of Agriculture and Pastoralism (Semi-domesutikeishon: Noko to Yuboku no Kigen Saikou). Tokyo: Kaimeisha; 1989 (In Japanese).

48. Kobayashi S: The Rehabilitation of Tropical Degraded Forest and Local Community Living with the Forest. Kyoto: Kyoto University; 2011.

49. Rennie SJ: Subsistence agriculture versus cash cropping - the social repercussions. J Rural Stud 1991, 7:5-9.

50. Garonna I, Fazey I, Brown ME, Pettorelli N: Rapid primary productivity changes in one of the last coastal rainforests: the case of Kahua, Solomon Islands. Environ Conserv 2009, 36:253-260.

51. Kenter JO, Hyde T, Christie M, Fazey I: The importance of deliberation in valuing ecosystem services in developing countries: evidence from the Solomon Islands. Global Environ Chang 2011, 21:505-521.

52. Kareiva P, Watts S, McDonald R, Boucher T: Domesticated nature: shaping landscapes and ecosystems for human welfare. Science 2007, 316:1866-1869.

53. Perfecto I, Vandermeer J: Biodiversity conservation in tropical agroecosystems: a new conservation paradigm. Annal NY Ac SC 2008, 1134:173-200 
54. Green RE, Cornell SJ, Scharlemann JP, Balmford A: Farming and the fate of wild nature. Science 2005, 307:550-555.

55. Goldman M: Partitioned nature, privileged knowledge: community-based conservation in Tanzania. Dev Change 2003, 34:833-862.

56. Furusawa T, Sasaoka M, Ohtsuka R: Living by utilizing various modified natural resources in the Solomon Islands. In Sustainable Use of Biological Diversity in Socio-ecological Production Landscapes, CBD Technical Series no. 52. Edited by Bélair C, Ichikawa K, Wong B, Mulongoy K. Montreal: Secretariat of the Convention on Biological Diversity; 2010:168-171.

doi:10.1186/1746-4269-10-10

Cite this article as: Furusawa et al: Interaction between forest

biodiversity and people's use of forest resources in Roviana, Solomon

Islands: implications for biocultural conservation under socioeconomic

changes. Journal of Ethnobiology and Ethnomedicine 2014 10:10.

\section{Submit your next manuscript to BioMed Central and take full advantage of:}

- Convenient online submission

- Thorough peer review

- No space constraints or color figure charges

- Immediate publication on acceptance

- Inclusion in PubMed, CAS, Scopus and Google Scholar

- Research which is freely available for redistribution 